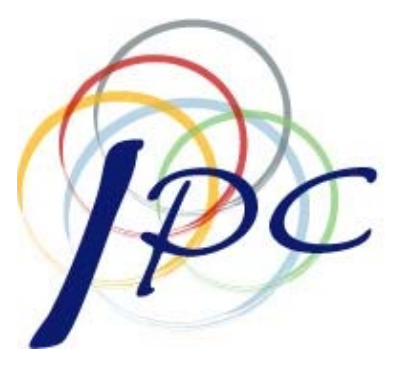

INTERNATIONAL Policy CENTER

Gerald R. Ford School of Public Policy University of Michigan

IPC Working Paper Series Number 108

Computational Analysis of the Menu of U.S. - Japan Trade Policies

Drusilla K. Brown

Kozo Kiyota

Robert M. Stern

October 8, 2010 


\title{
Computational Analysis of the Menu of U.S.-Japan Trade Policies
}

\author{
Drusilla K. Brown, Tufts University \\ Kozo Kiyota, Yokohama National University \\ Robert M. Stern, University of Michigan
}

\begin{abstract}
We have used the Michigan Computable General Equilibrium (CGE) Model of World Production and Trade to calculate the aggregate welfare and sectoral employment effects of the menu of U.S.-Japan trade policies. The menu of policies encompasses the various preferential U.S. and Japan bilateral and regional free trade agreements (FTAs) negotiated and in process, unilateral removal of existing trade barriers by the two countries, and global (multilateral) free trade. The U.S. preferential agreements include the FTAs approved by the U.S. Congress with Chile and Singapore in 2003, those signed with Central America, Australia, and Morocco and receiving Congressional approval in 2004, and prospective FTAs with the Southern African Customs Union (SACU), Thailand, and the Free Trade Area of the Americas (FTAA). The Japanese preferential agreements include the bilateral FTA with Singapore signed in 2002 and prospective FTAs with Chile, Indonesia, Korea, Malaysia, Mexico, Philippines, and Thailand. The welfare impacts of the FTAs on the United States and Japan are shown to be rather small in absolute and relative terms. The sectoral employment effects are also generally small in the United States and Japan, but vary across the individual sectors depending on the patterns of the bilateral liberalization. The welfare effects on the FTA partner countries are mostly positive though generally small, but there are some indications of potentially disruptive employment shifts in some partner countries. There are indications of trade diversion and detrimental welfare effects on nonmember countries for some of the FTAs analyzed. Data limitations precluded analysis of the welfare effects of the different FTA rules of origin and other discriminatory arrangements.
\end{abstract}

In comparison to the welfare gains from the U.S. and Japan bilateral FTAs, the gains from both unilateral trade liberalization by the United States, Japan, and the FTA partners, and from global (multilateral) free trade are shown to be rather substantial and more uniformly positive for all countries in the global trading system. The U.S. and Japan FTAs are based on "hub" and "spoke" arrangements. We show that the spokes emanate out in different and often overlapping directions, suggesting that the complex of bilateral FTAs may create distortions of the global trading system.

Keywords: Multilateral, Regional, and Bilateral Trade Liberalization; JEL: F10; F13; F15

October 8, 2010

Citation: Drusilla K. Brown, Kozo Kiyota, Robert M. Stern (2010), Chapter 11 Computational Analysis of the Menu of U.S.-Japan Trade Policies, in Professor Hamid Beladi, Professor E. Kwan Choi (ed.) New Developments in Computable General Equilibrium Analysis for Trade Policy (Frontiers of Economics and Globalization, Volume 7), Emerald Group Publishing Limited, pp.303-355 


\section{Computational Analysis of the Menu of U.S.-Japan Trade Policies*

\author{
Drusilla K. Brown, Tufts University \\ Kozo Kiyota, Yokohama National University**
} \\ Robert M. Stern, University of Michigan}

\section{Introduction}

In this paper, we present a computational analysis of the economic effects of the menu of U.S.-Japan trade policies. The menu encompasses the various U.S. and Japan bilateral and regional free trade agreements (FTAs) that had been negotiated and the negotiations currently in process in August 2004 when this paper was originally written, unilateral removal of existing trade barriers by the United States, Japan, and their FTA partner countries, and global (multilateral) free trade. The analysis is based on the Michigan Model of World Production and Trade. The Michigan Model is a multi-country/multi-sector computable general equilibrium (CGE) model of the global trading system that has been used for more than three decades to analyze the economic effects of multilateral, regional, and bilateral trade negotiations and a variety of other changes in trade and related policies.

In Section II following, we present a brief description of the main features and data of the Michigan Model. The results of the computational analysis of the U.S. and Japan FTAs are presented in Sections III and IV. In Section V, we consider the cross-country patterns of the welfare effects of the various FTAs. In Section VI, we provide a broader perspective on the FTAs that takes into account the effects of the unilateral and multilateral removal of trade barriers by the United States and Japan, their FTA partner countries, and other countries/regions in the global trading system. Section VII provides a summary and concluding remarks.

\footnotetext{
*This paper has been adapted from Brown, Kiyota, and Stern (2006). We wish to thank Masahiko Tsutsumi and participants in the March 2004 pre-conference meeting in Ann Arbor and the May 2004 Tokyo conference for helpful comments on earlier versions of the paper.

**Kozo Kiyota was a Visiting Scholar at the University of Michigan, Ann Arbor, when this paper was prepared and would like to thank the Kikawada Fellowship Program for providing financial support for the research.
} 


\section{The Michigan Model of World Production and Trade}

\section{Overview of the Michigan Model}

The version of the Michigan Model that we use in this paper covers 18 economic sectors, including agriculture, manufactures, and services, in each of 22 countries/regions. The distinguishing feature of the Michigan Model is that it incorporates some aspects of trade with imperfect competition, including increasing returns to scale, monopolistic competition, and product variety. Some details follow. ${ }^{1}$ A more complete description of the formal structure and equations of the model can be found on line at www.Fordschool.umich.edu/rsie/model/.

\section{Sectors and Market Structure}

As mentioned, the version of the model used consists of 18 production sectors and 22 countries/regions (plus rest-of-world). The sectoral and country/region coverage are indicated in the tables below. Agriculture is modeled as perfectly competitive with product differentiation by country of origin, and all other sectors covering manufactures and services are modeled as monopolistically competitive. Each monopolistically competitive firm produces a differentiated product and sets price as a profit-maximizing mark-up of price over marginal cost. Free entry and exit of firms then guarantees zero profits.

\section{Expenditure}

Consumers and producers are assumed to use a two-stage procedure to allocate expenditure across differentiated products. In the first stage, expenditure is allocated across goods without regard to the country of origin or producing firm. At this stage, the utility function is Cobb-Douglas, and the production function requires intermediate inputs in fixed proportions. In the second stage, expenditure on monopolistically competitive goods is allocated across the competing varieties supplied by each firm from all countries. In the perfectly competitive agricultural sector, since

\footnotetext{
${ }^{1}$ See also Deardorff and Stern (1990, esp. pp. 9-46) and Brown and Stern (1989a,b).
} 
individual firm supply is indeterminate, expenditure is allocated over each country's sector as a whole, with imperfect substitution between products of different countries.

The aggregation function in the second stage is a Constant Elasticity of Substitution (CES) function. Use of the CES function and product differentiation by firm imply that consumer welfare is influenced both by any reduction in real prices brought about by trade liberalization, as well as increased product variety. The elasticity of substitution among different varieties of a good is assumed to be three, a value that is broadly consistent with available empirical estimates. The parameter for the sensitivity of consumers to the number of product varieties is set at $0.5 .^{2}$

\section{Production}

The production function is separated into two stages. In the first stage, intermediate inputs and a primary composite of capital and labor are used in fixed proportion to output. ${ }^{3}$ In the second stage, capital and labor are combined through a CES function to form the primary composite. In the monopolistically competitive sectors, additional fixed inputs of capital and labor are required. It is assumed that fixed capital and fixed labor are used in the same proportion as variable capital and variable labor so that production functions are homothetic. The elasticities of substitution between capital and labor vary across sectors and were derived from a literature search of empirical estimates of sectoral supply elasticities. Economies of scale are determined endogenously in the model.

\section{Supply Prices}

To determine equilibrium prices, perfectly competitive firms operate such that price is equal to marginal cost, while monopolistically competitive firms maximize profits by setting price as an optimal mark-up over marginal cost. The numbers of firms in sectors under monopolistic

\footnotetext{
${ }^{2}$ If the variety parameter is greater than 0.5 , it means that consumers value variety more. If the parameter is zero, consumers have no preference for variety. This is the same as the Armington assumption according to which consumers view products as distinguished by country of production. Sensitivity tests of alternative parameter values are included in an appendix below.

${ }^{3}$ Intermediate inputs include both domestic and imported varieties.
} 
competition are determined by the zero profits condition. The free entry condition in this context is also the basic mechanism through which new product varieties are created (or eliminated). Each of the new entrants arrives with a distinctly different product, expanding the array of goods available to consumers.

Free entry and exit are also the means through which countries are able to realize the specialization gains from trade. In this connection, it can be noted that in a model with nationally differentiated products, which relies on the Armington assumption, production of a particular variety of a good cannot move from one country to another. In such a model, there are gains from exchange but no gains from specialization. However, in the Michigan Model with differentiated products supplied by monopolistically competitive firms, production of a particular variety is internationally mobile. A decline in the number of firms in one country paired with an expansion in another essentially implies that production of one variety of a good is being relocated from the country in which the number of firms is declining to the country in which the number of firms is expanding. Thus, we have both an exchange gain and a specialization gain from international trade. $^{4}$

\section{Capital and Labor Markets}

Capital and labor are assumed to be perfectly mobile across sectors within each country. Returns to capital and labor are determined so as to equate factor demand to an exogenous supply of each factor. The aggregate supplies of capital and labor in each country are assumed to remain fixed so as to abstract from macroeconomic considerations (e.g., the determination of investment), since our microeconomic focus is on the inter-sectoral allocation of resources.

\footnotetext{
${ }^{4}$ The international relocation of a particular variety of a good can be understood in the context of the ongoing outsourcing debate. Domestic firms require intermediate inputs, in addition to capital and labor. To the extent that tariff reduction leads a firm to substitute toward traded intermediate inputs, domestic firms can be thought of as outsourcing some component of production. This is particularly the case if there is a decline in the number of domestic firms in the sector from which intermediate inputs are purchased and an expansion in the supplier country.
} 


\section{World Market and Trade Balance}

The world market determines equilibrium prices such that all markets clear. Total demand for each firm or sector's product must equal total supply of that product. It is also assumed that trade remains balanced for each country/region, that is, any initial trade imbalance remains constant as trade barriers are changed. This is accomplished by permitting aggregate expenditure to adjust to maintain a constant trade balance. Thus, we abstract away from the macroeconomic forces and policies that are the main determinants of trade imbalances. Further, it should be noted that there are no nominal rigidities in the model. As a consequence, there is no role for a real exchange rate mechanism.

\section{Trade Policies and Rent/Revenues}

We have incorporated into the model the import tariff rates and export taxes/subsidies as policy inputs that are applicable to the bilateral trade of the various countries/regions with respect to one another. These have been computed using the "GTAP-5.4 Database" provided in Dimaranan and McDougall (2002). This was the latest database available at the time of writing in 2006. The export barriers have been estimated as export-tax equivalents. We assume that revenues from both import tariffs and export taxes, as well as rents from NTBs on exports, are redistributed to consumers in the tariff- or tax-levying country and are spent like any other income.

Tariff liberalization can affect economic efficiency through three main channels. First, in the context of standard trade theory, tariff reductions both reduce the cost of imports for consumers and for producers purchasing traded intermediate inputs, thus producing an exchange gain. Second, tariff removal leads firms to direct resources toward those sectors that have the greatest value on the world market. That is, we have the standard specialization gain. Third, tariff reductions have a procompetitive effect on sellers. Increased price pressure from imported varieties force incumbent firms to cut price. Surviving firms remain viable by expanding output, thereby moving down their 
average total cost (ATC) curve. The consequent lower ATC of production creates gains from the realization of economies of scale.

\section{Model Closure and Implementation}

We assume in the model that aggregate expenditure varies endogenously to hold aggregate employment constant. This closure is analogous to the Johansen closure rule (Deardorff and Stern, 1990, pp. 27-29). The Johansen closure rule consists of keeping the requirement of full employment while dropping the consumption function. This means that consumption can be thought of as adjusting endogenously to ensure full employment. However, in the present model, we do not distinguish consumption from other sources of final demand. That is, we assume instead that total expenditure adjusts to maintain full employment.

The model is solved using GEMPACK (Harrison and Pearson, 1996). When policy changes are introduced into the model, the method of solution yields percentage changes in sectoral employment and certain other variables of interest. Multiplying the percentage changes by the absolute levels of the pertinent variables in the database yields the absolute changes, positive or negative, which might result from the various liberalization scenarios.

\section{Interpreting the Modeling Results}

To help the reader interpret the modeling results, it is useful to review the features of the model that serve to identify the various economic effects to be reflected in the different applications of the model. Although the model includes the aforementioned features of imperfect competition, it remains the case that markets respond to trade liberalization in much the same way that they would with perfect competition. That is, when tariffs or other trade barriers are reduced in a sector, domestic buyers (both final and intermediate) substitute toward imports and the domestic competing industry contracts production while foreign exporters expand. Thus, in the case of multilateral liberalization that reduces tariffs and other trade barriers simultaneously in most sectors and countries, each country's industries share in both of these effects, expanding or 
contracting depending primarily on whether their protection is reduced more or less than in other sectors and countries.

Worldwide, these changes cause increased international demand for all sectors. World prices increase most for those sectors where trade barriers fall the most. ${ }^{5}$ This in turn causes changes in countries' terms of trade that can be positive or negative. Those countries that are net exporters of goods with the greatest degree of liberalization will experience increases in their terms of trade, as the world prices of their exports rise relative to their imports. The reverse occurs for net exporters in industries where liberalization is slight - perhaps because it may already have taken place in previous trade rounds.

The effects on the welfare of countries arise from a mixture of these terms-of-trade effects, together with the standard efficiency gains from trade and also from additional benefits due to the realization of economies of scale. Thus, we expect on average that the world will gain from multilateral liberalization, as resources are reallocated to those sectors in each country where there is a comparative advantage. In the absence of terms-of-trade effects, these efficiency gains should raise national welfare measured by the equivalent variation for every country, ${ }^{6}$ although some factor owners within a country may lose, as will be noted below. However, it is possible for a particular country whose net imports are concentrated in sectors with the greatest liberalization to lose overall, if the worsening of its terms of trade swamps these efficiency gains.

On the other hand, although trade with imperfect competition is perhaps best known for introducing reasons why countries may lose from trade, actually its greatest contribution is to expand the list of reasons for gains from trade. Thus, in the Michigan Model, trade liberalization permits all countries to expand their export sectors at the same time that all sectors compete more

\footnotetext{
${ }^{5}$ The price of agricultural products supplied by the rest of the world is taken as the numeraire in the model, and there is a rest-of-world against which all other prices can rise.

${ }^{6}$ The equivalent variation is a measure of the amount of income that would have to be given or taken away from an economy before a change in policy in order to leave the economy as well off as it would be after the policy change has taken place. If the equivalent variation is positive, it is indicative of an improvement in economic welfare resulting from the policy change.
} 
closely with a larger number of competing varieties from abroad. As a result, countries as a whole gain from lower costs due to increasing returns to scale, lower monopoly distortions due to greater competition, and reduced costs and/or increased utility due to greater product variety. All of these effects make it more likely that countries will gain from liberalization in ways that are shared across the entire population. ${ }^{7}$

The various effects just described in the context of multilateral trade liberalization will also take place when there is unilateral trade liberalization, although these effects will depend on the magnitudes of the liberalization in relation to the patterns of trade and the price and output responses involved between the liberalizing country and its trading partners. Similarly, many of the effects described will take place with the formation of bilateral or regional FTAs. But in these cases, there may be trade creation and positive effects on the economic welfare of FTA-member countries together with trade diversion and negative effects on the economic welfare of nonmember countries. The net effects on economic welfare for individual countries and globally will thus depend on the economic circumstances and policy changes implemented. ${ }^{8}$

In the real world, all of the various effects occur over time, some of them more quickly than others. However, the Michigan Model is static in the sense that it is based upon a single set of equilibrium conditions rather than relationships that vary over time. ${ }^{9}$ The model results

\footnotetext{
${ }^{7}$ In perfectly competitive trade models such as the Heckscher-Ohlin Model, one expects countries as a whole to gain from trade, but the owners of one factor - the "scarce factor" - to lose through the mechanism first explored by Stolper and Samuelson (1941). The additional sources of gain from trade due to increasing returns to scale, competition, and product variety, however, are shared across factors, and we routinely find in our CGE modeling that both labor and capital gain from multilateral trade liberalization.

${ }^{8}$ It may be noted that, in a model of perfect competition, bilateral trade liberalization should have the effect of contracting trade with the excluded countries, thereby improving the terms of trade for the FTA members vis-à-vis the rest of world. But in a model with scale economies, the pro-competitive effect of trade liberalization can generate a cut in price and increase in supply to excluded countries. The terms of trade of FTA members may therefore deteriorate in this event.

It should also be mentioned that rules of origin may offset some of the potential welfare benefits of FTAs insofar as they may lead to higher input costs and consequent reduction of FTA preference margins. In this connection, see Krishna (2004).

${ }^{9}$ As noted above, macroeconomic closure in the model involves the equivalent of having expenditure equal to the sum of earned incomes plus redistributed net tax revenues. However, the actual solution is attained indirectly, but equivalently, by imposing a zero change in the trade balance. Since the model allows for all
} 
therefore refer to a time horizon that depends on the assumptions made about which variables do and do not adjust to changing market conditions, and on the short- or long-run nature of these adjustments. Because the supply and demand elasticities used in the model reflect relatively long-run adjustments and it is assumed that markets for both labor and capital clear within countries, ${ }^{10}$ the modeling results are appropriate for a relatively long time horizon of several years - perhaps two or three at a minimum. On the other hand, the model does not allow for the very long-run adjustments that could occur through capital accumulation, population growth, and technological change. The modeling results should therefore be interpreted as being superimposed upon longer-run growth paths of the economies involved. To the extent that these growth paths themselves may be influenced by trade liberalization, therefore, the model does not capture such effects.

\section{Benchmark Data}

Needless to say, the data needs of this model are immense. Apart from numerous share parameters, the model requires various types of elasticity measures. Like other CGE models, most of our data come from published sources.

As mentioned above, the main data source used in the model is "The GTAP-5.4 Database" of the Purdue University Center for Global Trade Analysis Project (Dimaranan and McDougall, 2002). The reference year for this GTAP database is 1997. From this source, we have extracted the following data, aggregated to our sectors and countries/regions: ${ }^{11}$

\footnotetext{
net tax and tariff revenues to be redistributed to consumers, when tariffs are reduced with trade liberalization, the model implicitly imposes a non-distorting tax to recoup the loss in tariff revenues.

${ }^{10}$ The analysis in the model assumes throughout that the aggregate, economy-wide, level of employment is held constant in each country. The effects of trade liberalization are therefore not permitted to change any country's overall rates of employment or unemployment. This assumption is made because overall employment is determined by macroeconomic forces and policies that are not contained in the model and would not themselves be included in a negotiated trade agreement. The focus instead is on the composition of employment across sectors as determined by the microeconomic interactions of supply and demand resulting from the liberalization of trade.

${ }^{11}$ Details on the sectoral and country/region aggregation are available from the authors on request.
} 
- Bilateral trade flows among 22 countries/regions, decomposed into 18 sectors. Trade with the rest-of-world (ROW) is included to close the model.

- Input-output tables for the 22 countries/regions, excluding ROW

- Components of final demand along with sectoral contributions for the 22 countries/regions, excluding ROW

- Gross value of output and value added at the sectoral level for the 22 countries/regions, excluding ROW

- Bilateral import tariffs by sector among the 22 countries/regions

- Elasticity of substitution between capital and labor by sector

- Bilateral export-tax equivalents among the 22 countries/regions, decomposed into 18 sectors

The monopolistically competitive market structure in the nonagricultural sectors of the model imposes an additional data requirement of the numbers of firms at the sectoral level, and there is need also for estimates of sectoral employment. ${ }^{12}$ The employment data, which have been adapted from a variety of published sources, will be noted in tables below.

The GTAP-5.4 1997 database has been projected to the year 2005, which is when the Uruguay Round liberalization will have been fully implemented. In this connection, we extrapolated the labor availability in different countries/regions by an average weighted population growth rate of 1.2 percent per annum. All other major variables have been projected, using an average weighted growth rate of GDP of 2.5 percent. ${ }^{13}$ The 2005 data have been adjusted to take into account two major developments that have occurred in the global trading system since the mid-1990s. These include: (1) implementation of the Uruguay Round negotiations that were completed in 1993-94 and were to be phased in over the following decade;

\footnotetext{
${ }^{12}$ Notes on the construction of the data on the number of firms and for employment are available from the authors on request.

${ }^{13}$ The underlying data are drawn from World Bank sources and are available on request. For a more elaborate and detailed procedure for calculating year 2005 projections, see Hertel and Martin (2000 and 2001) and Hoekman and Martin (2001).
} 
and (2) the accession of Mainland China and Taiwan to the WTO in 2001. ${ }^{14}$ We have made allowance for the foregoing developments by readjusting the 2005 scaled-up database for benchmarking purposes to obtain an approximate picture of what the world may be expected to look like in 2005. In the computational scenarios to be presented below, we use these re-adjusted data as the starting point to carry out our liberalization scenarios for the U.S. bilateral FTAs and for the accompanying unilateral and global free trade scenarios.

The GTAP 5.4 (1997) base data for tariffs and the estimated tariff equivalents of services barriers are broken down by sector on a global basis and bilaterally for existing and prospective FTA partners of the United States and Japan in Tables 1-2. The post-Uruguay Round tariff rates on agriculture, mining, and manufactures are applied rates and are calculated in GTAP by dividing tariff revenues by the value of imports by sector.

The services barriers are based on financial data on average gross (price-cost) margins constructed initially by Hoekman (2000) and adapted for modeling purposes in Brown, Deardorff, and Stern (2002). The gross operating margins are calculated as the differences between total revenues and total operating costs. Some of these differences are presumably attributable to fixed costs. Given that the gross operating margins vary across countries, a portion of the margin can also be attributed to barriers to FDI. For this purpose, a benchmark is set for each sector in relation to the country with the smallest gross operating margin, on the assumption that operations in the benchmark country can be considered to be freely open to foreign firms. The excess in any other country above this lowest benchmark is then taken to be due to barriers to establishment by foreign firms.

\footnotetext{
${ }^{14}$ The tariff data for the WTO accession of China and Taiwan have been adapted from Ianchovichina and Martin (2004). In addition to benchmarking the effects of the Uruguay Round and China/Taiwan accession to the WTO, Francois et al. (2003) benchmark their GTAP 5.4 dataset to take into account the enlargement of the European Union (EU) in 2004 to include ten new member countries from Central and Eastern Europe and some changes in the EU Common Agricultural Policies that were introduced in 2000. Our EU and EFTA regional aggregate includes the 25-member EU, but the benchmark data were not adjusted to take into account the adoption of the EU common external tariffs by the new members. Because of data constraints, we have not made allowance for the Information Technology Agreement and agreements for liberalization of financial and telecommunication services following conclusion of the Uruguay Round.
} 
That is, the barrier is modeled as the cost-increase attributable to an increase in fixed cost borne by multinational corporations attempting to establish an enterprise locally in a host country. This abstracts from the possibility that fixed costs may differ among firms because of variations in market size, distance from headquarters, and other factors. It is further assumed that this cost increase can be interpreted as an ad valorem equivalent tariff on services transactions generally. It can be seen in Tables 1 and 2 that the constructed services barriers are considerably higher than the import barriers on manufactures. While possibly subject to overstatement, it is generally acknowledged that many services sectors are highly regulated and thus restrain international services transactions.

For the United States, the highest import tariffs for manufactures are recorded for textiles, wearing apparel, and leather products \& footwear, both globally and bilaterally. For Japan, the highest import tariffs are noted in agriculture, food, beverages \& tobacco, textiles, wearing apparel, and leather \& leather products. The values and shares of U.S. and Japanese exports and imports are broken down by sector according to origin and destination in Tables 3-6 on a global basis as well as for FTA partners. Employment by sector is indicated for the United States and for Japan and their FTA partners in Table 7.

\section{Computational Analysis of U.S. Free Trade Agreements}

As already noted, both the United States and Japan had signed or were in the process of negotiating bilateral FTAs in 2006, at the time of writing. For the United States, these include the agreements with Chile and Singapore approved by the U.S. Congress in 2003, agreements with Central America and the Dominican Republic (CAFTA), Australia, and Morocco to be submitted for Congressional approval in 2004, and ongoing negotiations with the Southern African Customs Union (SACU), Thailand, and the Free Trade Area of the Americas (FTAA). ${ }^{15}$ The Japanese

\footnotetext{
${ }^{15}$ It should be noted that the FTA negotiations with the SACU and Thailand have subsequently been suspended, and FTAA negotiations have been placed on hold. FTA negotiations were being concluded
} 
bilateral FTAs will be analyzed below and include the agreement with Singapore signed in 2002 and subsequent and prospective agreements with Chile, Korea, Malaysia, Mexico, Philippines, and Thailand.

As we note in Brown, Kiyota, and Stern (2005a,b,2007,2008), the United States has a myriad of objectives in pursuing FTAs, including increased market access and shaping the regulatory and political environment in FTA partner countries to conform to U.S. principles and institutions. By the same token, the FTA partners are attracted by the preferential margins for U.S. market access and opportunities to improve their economic efficiency and to design and implement more effective domestic institutions and policies. Similarly, Japan and its FTA partners are motivated by many of these objectives.

The U.S. FTAs to be analyzed are denoted as follows:

$\begin{array}{ll}\text { USCHFTA } & \text { U.S.-Chile FTA } \\ \text { USSGFTA } & \text { U.S.-Singapore FTA } \\ \text { USCAFTA } & \text { U.S.-Central America FTA } \\ \text { USAUSFTA } & \text { U.S.-Australia FTA } \\ \text { USMORFTA } & \text { U.S.-Morocco FTA } \\ \text { USSACUFTA } & \text { U.S.-Southern African Customs Union FTA } \\ \text { USTHFTA } & \text { U.S.-Thailand FTA } \\ \text { FTAA } & \text { Free Trade Area of the Americas }\end{array}$

Our reference point is the post-Uruguay Round 2005 database together with the postUruguay Round tariff rates on agricultural products and manufactures and the specially constructed measures of services barriers described above. Four scenarios have been carried out for each FTA: (A) removal of agricultural tariffs ${ }^{16}$; (M) removal of manufactures tariffs; (S) removal of services barriers; and (C) combined removal of agricultural and manufactures tariffs and services barriers. Because of space constraints, we report only the results of the combined

with Bahrain in 2004. An FTA with Peru was approved in 2009. Negotiations have been ongoing with Colombia, Korea, and Panama and are yet to be submitted for Congressional approval. See the USTR website for more information.

${ }^{16}$ The bilateral FTA scenarios in this and in the next section make no allowance for reductions in agricultural export subsidies and agricultural production subsidies, which are excluded from bilateral negotiations and fall within the scope of the multilateral negotiations. 
removal of agricultural and manufactures tariffs and services barriers, denoted by USCHFTA-C, etc. The results for the separate removal of the agricultural, manufactures, and services barriers and for the sectoral effects on exports, imports, and gross output are available on request.

We should emphasize that our computational analysis does not take into account other features of the various FTAs, which do not lend themselves readily to quantification. These other features cover E-commerce, intellectual property, labor and environmental standards, investment, government procurement, trade remedies, dispute settlement, and the development of new institutional and cooperative measures. By the same token, because of data constraints, we have not made allowance for rules of origin and special preferences that may be negotiated as part of each FTA and that could be designed for protectionist reasons to limit trade.

USCHFTA-C: U.S.-Chile Free Trade Agreement - The U.S.-Chile FTA was approved by the U.S. Congress in 2003. The estimated global welfare effects are indicated in Table 8. Global welfare increases by $\$ 7.9$ billion, with U.S. welfare increasing by $\$ 6.9$ billion $(0.1 \%$ of GNP) and Chile's welfare by $\$ 1.2$ billion (1.3\% of GNP). ${ }^{17}$ The sectoral results for the United States are shown in Table 9 and indicate relatively small employment declines in U.S. agriculture, food, beverages \& tobacco, wearing apparel, and leather products \& footwear, and employment increases in the other sectors. The sectoral employment effects for Chile are indicated in Table 10 and show employment increases in agriculture, mining, food, beverages \& tobacco, leather \& leather products, metal products, and trade and transport services, and employment declines in several manufacturing sectors and other services. These employment changes for Chile suggest the extent of labor market adjustments that may occur as a result of the FTA.

USSGFTA-C: U.S.-Singapore Free Trade Agreement - The welfare effects of a U.S.Singapore FTA, which was approved by the U.S. Congress in 2003, noted in Table 8, indicate an increase in global welfare of $\$ 22.5$ billion, with U.S. welfare rising by $\$ 15.8$ billion $(0.2 \%$ of

\footnotetext{
${ }^{17}$ The estimated effects on aggregate exports/imports, terms of trade, and real returns to capital and labor for this and all other FTAs to be analyzed in what follows are available from the authors on request. Changes in bilateral trade flows by country/region of origin and destination are also available.
} 
GNP) and Singapore's welfare by $\$ 2.5$ billion (2.6\% of GNP). In Table 9 , the sectoral employment effects for the United States are relatively small, whereas in Table 10, for Singapore, there are relatively large sectoral employment increases in textiles, wearing apparel, and services, and declines in most other sectors. These sectoral changes suggest sizable employment adjustments for Singapore that may occur in the FTA with the United States.

USCAFTA-C: U.S.-Central America Free Trade Agreement - The U.S.-CAFTA was signed in December 2003 and was subsequently approved by the U.S. Congress. The estimated global welfare effects are shown in Table 8. Global welfare rises by $\$ 15.7$ billion, U.S. welfare by $\$ 17.3$ billion ( $0.2 \%$ of GNP) and the welfare of the aggregate of Central American and the Caribbean (CAC) by $\$ 5.3$ (4.4\% of GNP). ${ }^{18,19}$ It can also be seen that the CAFTA is apparently trade diverting for most of the non-member countries/regions shown. The sectoral employment effects for the United States, noted in Table 9, indicate that. the employment declines are concentrated in textiles and wearing apparel and are comparatively small as a percent of employment in these sectors, $-0.6 \%$ and $-1.8 \%$, respectively. The sectoral employment changes

\footnotetext{
${ }^{18}$ The GTAP 5.4 data refer to a CAC aggregate and do not provide separate data for the five Central American countries and the Dominican Republic that comprise the CAFTA. It is noted in Brown, Kiyota, and Stern (2005b) that the CAFTA countries account for a substantial proportion of CAC trade so that using CAC data may be a reasonable approximation for modeling purposes.

${ }^{19}$ Andriamananjara and Tsigas (2003) use the standard GTAP model to analyze the welfare effects of bilateral U.S. FTAs with 65 countries/regions. This version of the GTAP model assumes constant returns to scale, perfect competition, and product differentiation by country of origin (the so-called Armington assumption). The Armington assumption implies that countries have monopoly power in their trading relationships, and that trade liberalization may thus have sizable terms-of-trade effects, depending on the structure and pattern of trade. There is reason to believe accordingly that welfare changes in this version of the GTAP model may reflect strong terms-of-trade effects. This is evident in the results of a U.S.-CAC FTA, which is estimated to increase U.S. economic welfare by $\$ 1.6$ billion (.02\% of GDP) and CAC welfare by $\$ 2.2$ billion (2.4\% of GDP). The decomposition of the results by the authors in their Appendix Table indicates that a substantial proportion of these welfare changes is due to changes in terms of trade. DeRosa and Gilbert (2004) also use the standard GTAP model to analyze U.S. bilateral FTAs with 13 prospective partner countries, and their results similarly suggest the predominance of terms of trade effects. In contrast, in the Michigan Model, manufactures and services products are differentiated by firm, so that countries have much less leverage over their terms of trade.
}

It should also be noted that, while the GTAP framework is structured to take shifts of productive resources into account and generates results for effects on real wages and the return to capital, the GTAP framework does not permit calculation of shifts in the sectoral employment of workers as is done in the Michigan Model. 
for the CAC are shown in Table 10. The increases are quite large in textiles, wearing apparel, and leather products \& footwear, and there are employment declines in all of the other sectors, as the expansion of the relatively labor-intensive industries attracts workers from the rest of the economy. These results thus suggest that the CAFTA may result in significant worker displacement in the process of adjustment brought about by elimination of the import barriers.

USAUSFTA-C: U.S.-Australia FTA - The U.S.-Australia FTA was signed in February 2004 and was later approved by the U.S. Congress. It can be seen in Table 8 that global welfare rises by $\$ 23.1$ billion, U.S. welfare by $\$ 19.4$ billion ( $0.2 \%$ of GNP), and Australian welfare by 5.4 billion (1.1\% of GNP). There are many instances of trade diversion for non-partner countries. The sectoral effects for the United States in Table 9 and for Australia in Table 10 indicate that the U.S.-Australia FTA will have fairly small effects on the sectoral employment in the two countries.

USMORFTA-C: U.S.-Morocco FTA - As noted in Tables 3-4 above, U.S. trade in goods and services with Morocco is rather small. By far the largest proportions of Morocco's trade are with the EU and EFTA. The global welfare increase from the U.S.-Morocco FTA indicated in Table 8 is $\$ 7.5$ billion, $\$ 6.0$ billion ( $0.1 \%$ of GNP) for the United States, and $\$ 0.9$ billion (2.0\% of GNP) for Morocco. ${ }^{20}$ The U.S. sectoral employment changes noted in Table 9 are negligible. For Morocco, in Table 10, the largest employment increases are in trade \& transport, textiles, and wearing apparel, and the largest declines in agriculture, food, beverages \& tobacco, and government services. The welfare and employment effects of the U.S.-Morocco FTA are thus seen to be fairly small.

USSACUFTA-C: U.S.-Southern African Customs Union - The effects of a U.S.SACU FTA are indicated in Table 8 and indicate an increase of $\$ 11.8$ billion in global welfare,

\footnotetext{
${ }^{20}$ Andriamananjara and Tsigas (2003, p. 16) estimate that the U.S.-Morocco FTA will reduce Morocco's economic welfare by $\$ 108$ million (-0.3\% of GDP) and will increase U.S. welfare by $\$ 161$ million (.002\% of GDP). Terms-of-trade effects are again evidently dominant, and, in any event, the overall welfare effects are much lower than the results based on the Michigan Model.
} 
$\$ 9.6$ billion ( $0.1 \%$ of GNP) for the United States, and $\$ 2.2$ billion (1.2\% of GNP) for the SACU members combined. In Table 9, there are indications of negligible sectoral employment impacts for the United States. In Table 10, the employment increases for SACU are concentrated in textiles and wearing apparel and are negative across the remaining sectors as labor is attracted towards the labor-intensive sectors.

US-THFTA-C: U.S.-Thailand FTA - In Table 8, the global welfare increase for the U.S.-Thailand FTA is $\$ 21.9$ billion, $\$ 17.1$ billion (0.2\% of GNP) for the United States, and $\$ 5.6$ billion (2.8\% of GNP) for Thailand. There is evidence of pervasive trade diversion. The sectoral employment changes for the United States noted in Table 9 are negligible. For Thailand, in Table 10, the largest employment increases are concentrated in food, beverages \& tobacco, textiles, wearing apparel, leather \& leather products, other manufactures, and trade \& transport, and there are employment declines especially in agriculture, mining, several capital-intensive manufactures, construction, other private services, and government services.

FTAA-C: Free Trade Area of the Americas - Discussions have been ongoing for several years to create a Free Trade Area for the Americas (FTAA). ${ }^{21}$ Since the country detail in our model does not include the individual members of the FTAA, we have chosen to approximate it by combining the United States, Canada, Mexico, and Chile with an aggregate of Central American and Caribbean (CAC) and an aggregate of other South American nations. The welfare effects of the FTAA are indicated in column Table 8 and amount to \$109.5 billion globally, \$67.6 billion ( $0.7 \%$ of GNP) for the United States, $\$ 5.8$ billion ( $0.7 \%$ of GNP) for Canada, $\$ 3.4$ billion (3.6\% of GNP) for Mexico, $\$ 3.4$ billion (3.6\% of GNP) for Chile, $\$ 7.8$ billion (6.5\% of GNP) for the CAC, and $\$ 27.6$ billion (1.5\% of GNP) for the aggregate of other South American countries. There is some evidence of trade diversion, in particular for Japan and the EU/EFTA. The sectoral employment effects for the United States, indicated in Table 11, show relatively small

\footnotetext{
${ }^{21}$ For details on the FTAA negotiations, see the website of the Office of the United States Trade Representative [www.ustr.gov].
} 
employment declines in agriculture, mining, food, beverages \& tobacco, and other private and government services, and increases in all other sectors. In Table 11, the sectoral employment effects for Canada are also small, whereas the employment increases for Mexico, Chile, the CAC, and other South America are noteworthy. This suggests that the developing countries covered in the FTAA would experience more employment adjustments than the United States and Canada.

\section{Computational Analysis of Japan's Free Trade Agreements}

In this section, we consider the welfare and sectoral employment effects of the JapanSingapore FTA that was concluded in 2002 and the FTAs in process with Chile, Indonesia, Korea, Malaysia, Mexico, Philippines, and Thailand. ${ }^{22}$ These are designated as follows:

$\begin{array}{ll}\text { JSGFTA } & \text { Japan-Singapore FTA } \\ \text { JCHFTA } & \text { Japan-Chile FTA } \\ \text { JINDFTA } & \text { Japan-Indonesia FTA } \\ \text { JKFTA } & \text { Japan-Korea FTA } \\ \text { JMAFTA } & \text { Japan-Malaysia FTA } \\ \text { JMXFTA } & \text { Japan-Mexico FTA } \\ \text { JPHFTA } & \text { Japan-Philippines FTA } \\ \text { JTHFTA } & \text { Japan-Thailand FTA }\end{array}$

As was the case for the U.S. FTAs analyzed in the previous section, we have undertaken separate computations for (A) removal of agricultural tariffs; (M) removal of manufactures tariffs; (S) removal of services barriers; and (C) combined removal of agricultural and manufactures tariffs and services barriers. In what follows, we report only the results of the combined removal of agricultural and manufactures tariffs and services barriers, denoted by JSGFTA-C, etc. The results for the separate removal of the agricultural, manufactures, and services barriers are available on request.

\footnotetext{
${ }^{22}$ It should be noted that the FTA negotiations were being concluded with Chile in 2007, Indonesia in 2008, Malaysia in 2006, Mexico in 2005, Philippines in 2008, and Thailand in 2007. FTA negotiations with Brunei, Vietnam, and Switzerland were also being concluded in 2008, 2009, and 2009, respectively. Negotiations have been ongoing with Korea, India, Australia, and the GCC (Gulf Cooperation Council). See the METI and MOFA websites for more information.
} 
JSGFTA-C: Japan-Singapore Free Trade Agreement - As shown in Table 12, the combined removal of bilateral tariffs on agricultural products and manufactures and services barriers would increase global economic welfare by $\$ 6.7$ billion. Japan’s welfare rises by $\$ 5.0$ billion ( $0.1 \%$ of GNP) and Singapore by $\$ 0.6$ billion ( $0.7 \%$ of GNP). A JSGFTA appears to be trade diverting to a small extent. The other industrialized countries besides Japan show increases in welfare. ${ }^{23}$ The sectoral results, which are shown Table 13, indicate negligible shifts in Japan's employment. For Singapore, as indicated in Table 14, there are employment increases especially in wearing apparel, leather \& leather products, and trade \& transport, and declines in many other manufacturing sectors and other private services. A Japan-Singapore FTA thus appears to have relatively small effects on Japan's welfare and results in sectoral employment shifts in Singapore away from capital-intensive towards relatively more labor-intensive sectors.

JCHFTA-C: Japan-Chile Free Trade Agreement - In Table 12, a JCHFTA indicates increases in global welfare of $\$ 3.5$ billion. Japan’s welfare rises by $\$ 2.8$ billion ( $0.1 \%$ of GNP), and Chile's welfare rises by $\$ 0.9$ billion (1.0\% of GNP). There are negative welfare effects for the United States, Canada, and several developing countries. The sectoral results for Japan, in Table 13, indicate negligible sectoral shifts. For Chile, as indicated in Table 14, there are employment increases in agriculture and food, beverages \& tobacco and declines in mining and all of the manufactures and services sectors as resources are shifted away from these sectors.

JINDFTA-C: Japan-Indonesia Free Trade Agreement - As indicated in Table 12, a JINDFTA increases global welfare by $\$ 11.1$ billion, Japan's welfare by $\$ 18.7$ billion $(0.2 \%$ of GNP), and Indonesia's welfare by $\$ 1.7$ billion ( $0.7 \%$ of GNP). There are indications of trade diversion and negative welfare effects for most of the non-member countries/regions. The

\footnotetext{
${ }^{23}$ See Hertel, Walmsley, and Itakura (2001) for a GTAP model-based analysis of the Japan-Singapore FTA that takes into account the proposed bilateral tariff reductions, implementation of uniform standards for ecommerce, services liberalization, the impact of automating customs procedures in Japan, and changes in foreign direct investment. They find that customs automization plays the most important role in driving increases in merchandise trade. They estimate global welfare gains of over $\$ 9$ billion, most of these gains accruing to Japan. They find no evidence of trade diversion.
} 
sectoral results for Japan in Table 13 show small negative employment effects on Japanese agriculture and labor-intensive manufactures and positive effects on most other sectors. For Indonesia, the sectoral employment effects mirror those in Japan, with employment expansion in Indonesian agriculture, food, beverages \& tobacco, and labor-intensive manufactures and employment declines in all other sectors.

JKFTA-C: Japan-Korea Free Trade Agreement - In Table 12, a JKFTA increases global welfare by $\$ 19.7$ billion, Japan’s welfare by $\$ 18.7$ billion ( $0.4 \%$ of GNP), and Korea’s welfare increases by $\$ 2.2$ billion ( $0.4 \%$ of GNP). There is some evidence of trade diversion for the United States, EU/EFTA, and for some developing countries. The sectoral results, shown in Table 13, indicate relatively small employment declines in Japan in agriculture and laborintensive manufactures, and increases in employment in durable manufactures and services. For Korea, as shown in Table 14, employment falls in many capital-intensive manufactures sectors and in services and rises in Korea's agriculture and labor-intensive manufactures. ${ }^{24}$

JMAFTA-C: Japan-Malaysia Free Trade Agreement - Global economic welfare is shown in Table 12 to increase by $\$ 10.1$ billion, Japan's welfare by $\$ 10.5$ billion ( $0.2 \%$ of GNP), and Malaysia’s welfare by $\$ 0.3$ billion $(0.2 \%$ of GNP). In Table 13 , sectoral employment declines in Japan’s agriculture, food, beverages \& tobacco, labor-intensive sectors, machinery \& equipment, and other manufactures, and there are employment increases in the other manufactures sectors and construction, other private services, and government services. For Malaysia, in Table 14, the employment increases are concentrated in agriculture, food, beverages \& tobacco, wearing apparel, wood \& wood products, and trade \& transport, and there are declines in capital-intensive manufactures and services except for trade \& transport.

\footnotetext{
${ }^{24}$ See McKibbin, Lee, and Cheong (2004) for an analysis of a Japan-Korea FTA, using the Asia-Pacific GCubed Model. The G-Cubed model incorporates rational expectations and forward-looking intertemporal behavior of individual agents. The model takes into account the induced changes in expected rates of return to capital by sector and consequent structural adjustments. Allowance is also made for short-term wage stickiness or adjustment costs in allocating capital. The authors conclude that Japan and Korea gain from a FTA, but there is trade diversion for the United States, Australia, and other countries. Their results also suggest greater benefits from a rapid liberalization rather than a more gradual phasing.
} 
JMXFTA-C: Japan-Mexico Free Trade Agreement - As indicated in Table 12, a JMXFTA increases global welfare by $\$ 10.6$ billion. Japan’s welfare increases by $\$ 8.2$ billion ( $0.2 \%$ of GNP) and Mexico’s welfare by $\$ 3.4$ billion ( $0.7 \%$ of GNP). There are indications that a JMXFTA would be trade diverting for the United States, Canada, EU/EFTA, and several developing countries. The sectoral results for Japan, shown in Table 13, indicate relatively small employment declines in agriculture, food, beverages \& tobacco, and labor-intensive manufactures and increases especially in durable manufactures. For Mexico, in Table 14, the sectoral results show relatively small employment increases in agriculture, food, beverages \& tobacco, and trade \& transport and declines across the manufactures sectors and services.

JPHFTA-C: Japan-Philippines FTA - In Table 12, global welfare increases by $\$ 3.0$ billion, Japan's welfare by $\$ 2.2$ billion ( $0.1 \%$ of GNP), and the Philippines welfare by $\$ 0.5$ billion ( $0.6 \%$ of GNP). The sectoral employment results for Japan, noted in Table 13, indicate declines in agriculture and food, beverages \& tobacco, and labor-intensive manufactures and increases in the other manufactures sectors and services. For the Philippines, in Table 14, the employment shifts mirror those in Japan, with increases concentrated in agriculture, food, beverages \& tobacco and labor-intensive manufactures and declines across other manufactures and services.

JTHFTA-C: Japan-Thailand FTA - In Table 12, a Japan-Thailand FTA increases global welfare by $\$ 13.5$ billion and Japan’s welfare by $\$ 19.5$ billion ( $0.4 \%$ of GNP), and reduces Thailand's welfare by $\$ 0.5$ billion ( $-0.3 \%$ of GNP). There are indications of trade diversion across most of the other countries/regions indicated. There are sectoral employment declines in Japan, noted in Table 13, in agriculture, food, beverages \& tobacco, and labor-intensive sectors and employment increases in capital-intensive manufactures and services. For Thailand, in Table 14, the employment increases are concentrated in agriculture and food, beverages \& tobacco and employment declines across the manufactures and services sectors. The reduction in Thailand's welfare stems from the shifts away from the manufactures sectors, which are modeled with 
increasing returns to scale, to the agricultural sector, which is modeled with constant returns to scale.

\section{Hub and Spoke Effects of the U.S. and Japan FTAs}

In the discussion of the U.S. and Japan bilateral FTAs in the preceding sections, it was noted that there were indications of negative welfare effects for a number of non-member countries/regions. It is well known theoretically that preferential trading arrangements may result in both trade creation, which is welfare enhancing, and trade diversion, which will reduce welfare as trade is shifted from lower to higher cost sources of supply. But there is another consideration, which is that bilateral FTAs are based on the "hub-and-spoke" arrangement, with the United States or Japan representing the hub and with separate spokes connecting the bilateral FTA partners to the hub. In negotiating these bilateral FTAs, no account is taken of the effects that they may have on non-members, even though there may be a bilateral FTA with one or more of the non-members. As more and more bilateral FTAs are negotiated, the spokes of the FTAs may thus emanate out in many different and overlapping directions, with resulting distortions of global trade patterns. That is, this combination of varying preferences among different and overlapping FTAs may lead to greatly increased transactions costs for firms and the undermining of the mostfavored-nation (MFN) principle of non-discrimination that is at the heart of the multilateral

trading system. These effects of the proliferation of FTAs are what Bhagwati and Panagariya (1996) refer to as "spaghetti-bowl" effects.

An indication of the trade diversion associated with the U.S. and Japan FTAs and the overlapping of the spokes involved is shown in the top half of Table 15, which has shaded cells indicating cases of positive welfare effects and white cells indicating cases of negative welfare effects. Altogether, 16 FTAs are shown, although there is some double counting insofar as the U.S.-CAC and U.S.-Chile bilateral FTAs are encompassed in the FTAA. In any event, it seems evident from Table 15 that trade diversion and negative welfare effects are pervasive. Thus, 
while partner-FTA countries may gain directly from their FTAs, as indicated by "X" in the table, they may be adversely affected by other FTAs that have been negotiated.

The global results of the bilateral FTAs in Tables 8 and 12 above for the United States and Japan suggest that the negative welfare effects on non-members may be rather small in both absolute terms and as a percent of GNP. But, as mentioned in our earlier discussion, because of data limitations, our results do not reflect the potential welfare declines due to rules of origin and other discriminatory arrangements built into the bilateral FTAs. On the other hand, we do not allow for increased inflows of foreign direct investment into the partner countries or the effects of improvements in productivity and increased capital formation. Unfortunately, we are not in a position to assess these potential benefits. But it seems clear from our computational results that the welfare increases from the FTA removal of trade barriers are fairly small on the whole. Pending further analysis, we therefore conclude that there is reason to be concerned about the trade diversion and overlapping spoke effects of bilateral FTAs.

\section{Welfare Effects of Unilateral Free Trade and Global Free Trade}

In this section, we ask how the welfare of the United States, Japan, their FTA partners, and other countries/regions in the global trading system would be affected if it were feasible to adopt unilateral free trade or global free trade on a non-discriminatory (MFN) basis. as compared to the adoption of discriminatory bilateral FTAs. The results are indicated in Table 16. Unilateral free trade adopted by the United States would increase U.S. welfare by $\$ 320.2$ billion (3.2\% of GNP), which is about three times greater than the U.S. welfare gains from the bilateral FTAs combined. If there were global (multilateral) free trade, U.S. welfare would be increased by \$401.8 billion (5.4\% of GNP). Japan's welfare would increase with unilateral free trade by $\$ 200.3$ billion (3.7\% of GNP) and with global free trade by $\$ 542.5$ billion (7.4\% of GNP), as compared to the $\$ 66.9$ billion to be gained from Japan’s bilateral FTAs combined. There are also clear indications that the FTA partner countries would generally gain more from the adoption of 
unilateral free trade by the United States and Japan as compared to the partner-country gains from their bilateral FTAs. Furthermore, the FTA partner countries would generally gain even more if they adopted unilateral free trade and especially if there were global free trade. ${ }^{25}$

\section{Summary and Conclusions}

In this paper, we have used the Michigan Model of World Production and Trade to calculate the aggregate welfare and sectoral employment effects of the menu of U.S.-Japan trade policies. The menu of policies encompasses the various preferential U.S. and Japan bilateral and regional FTAs negotiated and in process, unilateral removal of existing trade barriers by the United States, Japan, and the FTA partner countries, and global (multilateral) free trade. The welfare impacts of the FTAs on the United States and Japan have been shown to be rather small in absolute and relative terms. The sectoral employment effects are also generally small for both countries, but vary across the individual sectors depending on the patterns of bilateral liberalization.

The welfare effects on the FTA partner countries are shown to be mostly positive though generally small, but there are some indications of potentially disruptive employment shifts in some partner countries. The results further suggest that there would be trade diversion and detrimental welfare effects in some non-member countries/regions. It also appears that, while

\footnotetext{
${ }^{25}$ In commenting on an earlier version of our paper, Juan Carlos Hallak asked why there are larger absolute welfare gains and smaller percent changes in welfare for the large countries as compared to the small countries in our computational results. In this connection, the expectation is that, under conditions of perfect competition, a small country may appropriate a large share of the absolute gains from trade liberalization because the prices of the small country will tend to move towards the prices in the large country. Since large price changes give rise to large gains from trade, the small country may be expected therefore to realize greater gains from liberalization than the large country.

But when scale effects are present, as in the Michigan Model, the foregoing distributional logic may not hold. That is, scale gains will be substantial for countries that specialize in sectors with significant unrealized scale economies, and it may well be that large countries are in a better position to realize big scale gains. Also, the pro-competitive effects resulting from liberalization may produce efficiency gains throughout an industry. As a consequence, the absolute gain will be proportional to the industry's/country's size. With regard to percent changes, however, there is reason to believe that a large country will exert stronger pro-competitive forces on a small country, than vice versa. We might therefore expect to observe larger percent changes in scale in small as compared to large countries. This is borne out in our calculations of scale effects for the countries/regions in the various liberalization scenarios that we have run, the results of which are available on request.
} 
FTA partners may gain from the bilateral FTAs, they may be adversely affected because of overlapping "hub-and-spoke" arrangements due to other discriminatory FTAs that have been negotiated.

The welfare gains from both unilateral trade liberalization by the United States and Japan and from global (multilateral) trade liberalization are shown to be rather substantial and more uniformly positive for all countries/regions in the global trading system as compared to the welfare gains from the bilateral FTAs analyzed. ${ }^{26}$ The issue then is whether and when the WTO member countries will be able to overcome their divisiveness and indecisions and put the multilateral negotiations back on track. The menu choice appears to be clear.

\footnotetext{
${ }^{26}$ See the appendix below for sensitivity analysis of introducing alternative parameters in the model and the resulting welfare impacts of global free trade.
} 


\section{Appendix}

\section{Sensitivity Analysis}

This appendix reports on sensitivity analysis of the Michigan Model. There are three key elasticities/parameters in the Model: the elasticity of substitution among varieties, which is exogenously set at three; the parameter that measures the sensitivity that consumers have to the number of varieties, which is set at 0.5 ; and the elasticities of supply that are taken from the literature.

The variety parameter can take on values between zero and one. The larger it is, it means that consumers value variety more. If the parameter is set at zero, consumers have no preference for variety. This would correspond to the Armington assumption, according to which consumers view products depending on their place of production..

To analyze the sensitivity of our model results, we have experimented with different values of the elasticity of substitution among varieties and the consumer sensitivity to the number of varieties. The following tests were conducted: (1) increase the elasticity of substitution among varieties by 10 percent, holding other parameters constant; (2) decrease the elasticity of substitution by 10 percent, holding other parameters constant; (3) increase the consumption varieties parameter by 10 percent, holding other parameters constant; and (4) decrease the consumption varieties by 10 percent, holding other parameters constant.

The results, which are available on request, are not very sensitive to the alternative parameters of the consumption varieties. That is, a 10 percent increase (decrease) in these parameters yields only 2 percent larger (smaller) welfare effects compared to the baseline model. The sensitivity to the changes in the elasticity of substitution is large compared with the results of differences in the variety parameters. For some countries, the differences are greater than 10 percent

In Brown, Deardorff, and Stern (2000), sensitivity tests reveal that the model may exaggerate the likely gains from economies of scale due to trade liberalization in the context of expansion of the NAFTA. But the error is small in this context because the impact of trade liberalization is small. When econometric estimates of scale economies are incorporated into the model, the welfare gains due to capital flows are shown to remain robust. 


\section{Tables}

(Percent)

\begin{tabular}{|c|c|c|c|c|c|c|c|c|c|c|c|}
\hline & \multirow{2}{*}{ Global } & \multirow{2}{*}{ Singapore } & \multirow{2}{*}{ Australia } & \multirow{2}{*}{ Morocco } & \multirow{2}{*}{ SACU } & \multirow{2}{*}{ Thailand } & \multicolumn{5}{|c|}{ FTAA } \\
\hline & & & & & & & Canada & CAC & Chile & Mexico & $\begin{array}{c}\text { South } \\
\text { America }\end{array}$ \\
\hline Agriculture & 2.7 & 0.1 & 4.0 & 0.1 & 1.3 & 0.3 & 0.0 & 1.0 & 0.8 & 0.0 & 3.2 \\
\hline Mining & 0.2 & 0.0 & 0.3 & 0.0 & 0.1 & 0.0 & 0.0 & 0.3 & 0.1 & 0.0 & 0.1 \\
\hline Food, Beverages \& Tobacco & 3.5 & 1.2 & 3.4 & 2.8 & 2.8 & 1.4 & 0.0 & 3.0 & 1.3 & 0.0 & 1.8 \\
\hline Textiles & 5.7 & 9.3 & 6.5 & 7.1 & 6.3 & 8.7 & 0.0 & 6.8 & 14.0 & 0.0 & 7.7 \\
\hline $\begin{array}{l}\text { Wearing Apparel } \\
\text { Leather Products \& }\end{array}$ & 11.0 & 15.5 & 9.7 & 10.5 & 12.4 & 14.2 & 0.0 & 11.6 & 11.5 & 0.0 & 13.6 \\
\hline Footwear & 7.2 & 5.6 & 4.1 & 3.6 & 2.3 & 7.7 & 0.0 & 4.6 & 7.7 & 0.0 & 6.3 \\
\hline Wood \& Wood Products & 0.3 & 0.4 & 0.8 & 0.7 & 0.3 & 0.2 & 0.0 & 0.5 & 0.2 & 0.0 & 0.4 \\
\hline Chemicals & 1.9 & 3.2 & 1.0 & 1.0 & 0.7 & 1.8 & 0.0 & 0.8 & 0.0 & 0.0 & 0.9 \\
\hline Non-metallic Min. Products & 3.2 & 4.0 & 2.9 & 0.9 & 0.0 & 2.8 & 0.0 & 3.8 & 0.6 & 0.0 & 2.3 \\
\hline Metal Products & 1.4 & 2.3 & 0.2 & 1.4 & 0.6 & 0.9 & 0.0 & 0.5 & 0.5 & 0.0 & 0.6 \\
\hline Transportation Equipment & 1.2 & 1.0 & 1.5 & 0.3 & 1.7 & 0.1 & 0.0 & 1.3 & 1.4 & 0.0 & 0.2 \\
\hline Machinery \& Equipment & 1.0 & 0.8 & 1.6 & 0.0 & 0.1 & 0.1 & 0.0 & 0.3 & 0.2 & 0.0 & 0.4 \\
\hline Other Manufactures & 1.3 & 1.3 & 0.9 & 0.0 & 0.4 & 0.4 & 0.0 & 2.2 & 0.1 & 0.0 & 1.5 \\
\hline Elec., Gas \& Water & 0.0 & 0.0 & 0.0 & 0.0 & 0.0 & 0.0 & 0.0 & 0.0 & 0.0 & 0.0 & 0.0 \\
\hline Construction & 9.0 & 9.0 & 9.0 & 9.0 & 9.0 & 9.0 & 0.0 & 9.0 & 9.0 & 0.0 & 9.0 \\
\hline Trade \& Transport & 27.0 & 27.0 & 27.0 & 27.0 & 27.0 & 27.0 & 0.0 & 27.0 & 27.0 & 0.0 & 27.0 \\
\hline Other Private Services & 31.0 & 31.0 & 31.0 & 31.0 & 31.0 & 31.0 & 0.0 & 31.0 & 31.0 & 0.0 & 31.0 \\
\hline Government Services & 25.0 & 25.0 & 25.0 & 25.0 & 25.0 & 25.0 & 0.0 & 25.0 & 25.0 & 0.0 & 25.0 \\
\hline
\end{tabular}

Note: Central America and Caribbean (CAC) members include Costa Rica, Dominican Republic, El Salvador, Guatemala, Honduras, and Nicaragua, and are to be included in the FTAA.

Sources: Adapted from Francois and Strutt (1999); Brown, Deardorff and Stern (2002); and Diamaranan and McDougall (2002). 
Table 2. Post-Uruguay Round Tariff Rates by Sector for Japan

\begin{tabular}{|c|c|c|c|c|c|c|c|c|c|}
\hline \multicolumn{10}{|c|}{ (Percent) } \\
\hline & Global & Singapore & Chile & Korea & Indonesia & Malaysia & Mexico & Philippines & Thailand \\
\hline Agriculture & 38.1 & 1.3 & 2.9 & 5.3 & 6.7 & 0.3 & 6.1 & 11.5 & 1.7 \\
\hline Food, Beverages \& Tobacco & 25.2 & 20.8 & 4.3 & 18.9 & 3.2 & 2.2 & 44.2 & 4.6 & 17.3 \\
\hline Textiles & 2.8 & 7.4 & 0.0 & 2.9 & 1.1 & 0.2 & 0.1 & 1.7 & 1.5 \\
\hline Wearing Apparel & 6.5 & 5.8 & 7.0 & 5.8 & 5.4 & 5.7 & 5.1 & 4.9 & 4.9 \\
\hline Leather Products \& Footwear & 8.9 & 6.1 & 0.0 & 8.4 & 4.5 & 9.1 & 10.3 & 8.0 & 8.4 \\
\hline Wood \& Wood Products & 0.4 & 0.3 & 0.1 & 0.2 & 0.0 & 0.3 & 0.5 & 0.0 & 0.0 \\
\hline Chemicals & 1.8 & 0.9 & 0.0 & 0.9 & 1.1 & 0.3 & 0.6 & 0.4 & 0.6 \\
\hline Non-metallic Min. Products & 1.0 & 0.2 & 0.0 & 0.7 & 1.4 & 0.4 & 0.9 & 0.6 & 1.4 \\
\hline Metal Products & 0.5 & 0.3 & 0.1 & 1.0 & 0.3 & 0.3 & 0.1 & 0.3 & 0.4 \\
\hline Transportation Equipment & 0.0 & 0.0 & 0.0 & 0.0 & 0.0 & 0.0 & 0.0 & 0.0 & 0.0 \\
\hline Other Manufactures & 0.7 & 0.0 & 1.8 & 0.3 & 2.8 & 0.0 & 0.0 & 0.8 & 0.1 \\
\hline Elec., Gas \& Water & 0.0 & 0.0 & 0.0 & 0.0 & 0.0 & 0.0 & 0.0 & 0.0 & 0.0 \\
\hline Construction & 3.0 & 3.0 & 3.0 & 3.0 & 0.0 & 3.0 & 3.0 & 3.0 & 3.0 \\
\hline Trade \& Transport & 15.0 & 15.0 & 15.0 & 15.0 & 15.0 & 15.0 & 15.0 & 15.0 & 15.0 \\
\hline Other Private Services & 12.0 & 12.0 & 12.0 & 12.0 & 12.0 & 12.0 & 12.0 & 12.0 & 12.0 \\
\hline Government Services & 28.0 & 28.0 & 28.0 & 28.0 & 28.0 & 28.0 & 28.0 & 28.0 & 28.0 \\
\hline
\end{tabular}

Sources: Adapted from Francois and Strutt (1999); Brown, Deardorff and Stern (2002); and Diamaranan and McDougall (2002). 
Table 3. Value of U.S. Sectoral Exports by Destination and Origin, 1997 (Millions of U.S. Dollars)

\begin{tabular}{|c|c|c|c|c|c|c|c|c|c|c|c|}
\hline \multirow[b]{2}{*}{ Value } & \multirow[t]{2}{*}{ Global } & \multirow[t]{2}{*}{ Singapore } & \multirow[t]{2}{*}{ Australia } & \multirow[t]{2}{*}{ Morocco } & \multirow[t]{2}{*}{ SACU } & \multirow[t]{2}{*}{ Thailand } & \multicolumn{5}{|c|}{ 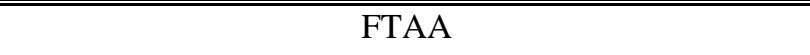 } \\
\hline & & & & & & & Canada & CAC & Chile & Mexico & $\begin{array}{c}\text { South } \\
\text { America }\end{array}$ \\
\hline Agriculture & 35,176 & 121 & 109 & 128 & 65 & 394 & 2,815 & 1,098 & 47 & 3,242 & 1,547 \\
\hline Mining & 6,421 & 15 & 22 & 6 & 38 & 6 & 1,416 & 26 & 39 & 214 & 434 \\
\hline Food, Beverages \& Tobacco & 30,541 & 293 & 281 & 75 & 145 & 171 & 3,964 & 1,464 & 83 & 2,065 & 982 \\
\hline Textiles & 11,485 & 113 & 159 & 11 & 36 & 56 & 2,538 & 1,362 & 90 & 2,055 & 565 \\
\hline Wearing Apparel & 6,847 & 45 & 35 & 4 & 8 & 12 & 423 & 2,428 & 21 & 1,623 & 213 \\
\hline Leather Products \& Footwear & 2,280 & 24 & 24 & 0 & 16 & 37 & 185 & 213 & 6 & 323 & 59 \\
\hline Wood \& Wood Products & 29,386 & 284 & 542 & 8 & 165 & 182 & 7,717 & 1,094 & 151 & 3,415 & 1,371 \\
\hline Chemicals & 90,569 & 3,236 & 2,129 & 26 & 524 & 1,109 & 15,886 & 2,737 & 665 & 10,405 & 6,752 \\
\hline Non-metallic Min. Products & 11,921 & 168 & 318 & 20 & 96 & 68 & 2,703 & 269 & 93 & 922 & 745 \\
\hline Metal Products & 34,238 & 511 & 312 & 1 & 97 & 384 & 10,460 & 712 & 223 & 5,089 & 1,447 \\
\hline Transportation Equipment & 102,640 & 1,899 & 1,800 & 89 & 349 & 1,337 & 33,595 & 953 & 607 & 8,130 & 3,713 \\
\hline Machinery \& Equipment & 269,892 & 11,075 & 5,440 & 77 & 1,367 & 3,455 & 44,683 & 3,795 & 1,860 & 27,568 & 17,262 \\
\hline Other Manufactures & 11,322 & 254 & 210 & 2 & 55 & 49 & 1,400 & 273 & 69 & 794 & 526 \\
\hline Elec., Gas \& Water & 751 & 19 & 4 & 0 & 2 & 4 & 113 & 2 & 2 & 9 & 60 \\
\hline Construction & 4,023 & 2 & 3 & 0 & 4 & 32 & 5 & 32 & 0 & 2 & 9 \\
\hline Trade \& Transport & 81,445 & 879 & 1,675 & 60 & 549 & 602 & 2,401 & 514 & 308 & 744 & 3,069 \\
\hline Other Private Services & 81,707 & 1,280 & 1,047 & 66 & 315 & 975 & 3,889 & 588 & 151 & 928 & 2,195 \\
\hline Government Services & 42,165 & 366 & 574 & 321 & 250 & 309 & 826 & 282 & 139 & 722 & 1,759 \\
\hline Total & 852,808 & 20,583 & 14,686 & 894 & 4,080 & 9,183 & 135,019 & 17,843 & 4,554 & 68,250 & 42,708 \\
\hline
\end{tabular}




\begin{tabular}{|c|c|c|c|c|c|c|c|c|c|c|c|}
\hline \multirow[b]{2}{*}{ Percent } & \multirow[t]{2}{*}{ Global } & \multirow[t]{2}{*}{ Singapore } & \multirow[t]{2}{*}{ Australia } & \multirow[t]{2}{*}{ Morocco } & \multirow[t]{2}{*}{ SACU } & \multirow[t]{2}{*}{ Thailand } & \multicolumn{5}{|c|}{ FTAA } \\
\hline & & & & & & & Canada & CAC & Chile & Mexico & $\begin{array}{c}\text { South } \\
\text { America }\end{array}$ \\
\hline Agriculture & 100.0 & 0.3 & 0.3 & 0.4 & 0.2 & 1.1 & 8.0 & 3.1 & 0.1 & 9.2 & 4.4 \\
\hline Mining & 100.0 & 0.2 & 0.3 & 0.1 & 0.6 & 0.1 & 22.0 & 0.4 & 0.6 & 3.3 & 6.8 \\
\hline Food, Beverages \& Tobacco & 100.0 & 1.0 & 0.9 & 0.2 & 0.5 & 0.6 & 13.0 & 4.8 & 0.3 & 6.8 & 3.2 \\
\hline Textiles & 100.0 & 1.0 & 1.4 & 0.1 & 0.3 & 0.5 & 22.1 & 11.9 & 0.8 & 17.9 & 4.9 \\
\hline Wearing Apparel & 100.0 & 0.7 & 0.5 & 0.1 & 0.1 & 0.2 & 6.2 & 35.5 & 0.3 & 23.7 & 3.1 \\
\hline Leather Products \& Footwear & 100.0 & 1.0 & 1.0 & 0.0 & 0.7 & 1.6 & 8.1 & 9.3 & 0.3 & 14.2 & 2.6 \\
\hline Wood \& Wood Products & 100.0 & 1.0 & 1.8 & 0.0 & 0.6 & 0.6 & 26.3 & 3.7 & 0.5 & 11.6 & 4.7 \\
\hline Chemicals & 100.0 & 3.6 & 2.4 & 0.0 & 0.6 & 1.2 & 17.5 & 3.0 & 0.7 & 11.5 & 7.5 \\
\hline Non-metallic Min. Products & 100.0 & 1.4 & 2.7 & 0.2 & 0.8 & 0.6 & 22.7 & 2.3 & 0.8 & 7.7 & 6.3 \\
\hline Metal Products & 100.0 & 1.5 & 0.9 & 0.0 & 0.3 & 1.1 & 30.6 & 2.1 & 0.7 & 14.9 & 4.2 \\
\hline Transportation Equipment & 100.0 & 1.9 & 1.8 & 0.1 & 0.3 & 1.3 & 32.7 & 0.9 & 0.6 & 7.9 & 3.6 \\
\hline Machinery \& Equipment & 100.0 & 4.1 & 2.0 & 0.0 & 0.5 & 1.3 & 16.6 & 1.4 & 0.7 & 10.2 & 6.4 \\
\hline Other Manufactures & 100.0 & 2.2 & 1.9 & 0.0 & 0.5 & 0.4 & 12.4 & 2.4 & 0.6 & 7.0 & 4.6 \\
\hline Elec., Gas \& Water & 100.0 & 2.5 & 0.6 & 0.0 & 0.2 & 0.5 & 15.1 & 0.3 & 0.2 & 1.3 & 8.0 \\
\hline Construction & 100.0 & 0.1 & 0.1 & 0.0 & 0.1 & 0.8 & 0.1 & 0.8 & 0.0 & 0.0 & 0.2 \\
\hline Trade \& Transport & 100.0 & 1.1 & 2.1 & 0.1 & 0.7 & 0.7 & 2.9 & 0.6 & 0.4 & 0.9 & 3.8 \\
\hline Other Private Services & 100.0 & 1.6 & 1.3 & 0.1 & 0.4 & 1.2 & 4.8 & 0.7 & 0.2 & 1.1 & 2.7 \\
\hline Government Services & 100.0 & 0.9 & 1.4 & 0.8 & 0.6 & 0.7 & 2.0 & 0.7 & 0.3 & 1.7 & 4.2 \\
\hline Total & 100.0 & 2.4 & 1.7 & 0.1 & 0.5 & 1.1 & 15.8 & 2.1 & 0.5 & 8.0 & 5.0 \\
\hline
\end{tabular}

Source: GTAP 5.4 adapted from Dimaranan and McDougall (2002). 
Table 4. Value of U.S. Sectoral Imports by Destination and Origin, 1997 (Millions of U.S. Dollars)

\begin{tabular}{|c|c|c|c|c|c|c|c|c|c|c|c|}
\hline \multirow[b]{2}{*}{ Value } & \multirow[t]{2}{*}{ Global } & \multirow[t]{2}{*}{ Singapore } & \multirow[t]{2}{*}{ Australia } & \multirow[t]{2}{*}{ Morocco } & \multirow[t]{2}{*}{$\overline{\mathrm{SACU}}$} & \multirow[t]{2}{*}{ Thailand } & \multicolumn{5}{|c|}{$\overline{\text { FTAA }}$} \\
\hline & & & & & & & Canada & CAC & Chile & Mexico & $\begin{array}{c}\text { South } \\
\text { America }\end{array}$ \\
\hline Agriculture & 18,602 & 41 & 181 & 15 & 53 & 207 & 3,984 & 2,280 & 716 & 2,956 & 3,585 \\
\hline Mining & 69,939 & 0 & 413 & 72 & 133 & 13 & 17,060 & 664 & 74 & 8,324 & 12,894 \\
\hline Food, Beverages \& Tobacco & 28,813 & 115 & 898 & 41 & 138 & 1,672 & 5,553 & 1,421 & 534 & 1,957 & 2,427 \\
\hline Textiles & 21,514 & 132 & 169 & 4 & 101 & 389 & 1,803 & 1,725 & 9 & 2,640 & 365 \\
\hline Wearing Apparel & 38,335 & 186 & 45 & 62 & 139 & 1,212 & 1,050 & 5,443 & 17 & 3,974 & 612 \\
\hline Leather Products \& Footwear & 21,842 & 9 & 28 & 5 & 25 & 782 & 219 & 438 & 5 & 607 & 1,572 \\
\hline Wood \& Wood Products & 43,785 & 211 & 85 & 4 & 81 & 353 & 25,258 & 165 & 352 & 2,956 & 1,216 \\
\hline Chemicals & 77,142 & 864 & 302 & 11 & 259 & 702 & 15,449 & 879 & 159 & 2,747 & 4,414 \\
\hline Non-metallic Min. Products & 14,071 & 17 & 40 & 2 & 44 & 161 & 2,572 & 369 & 18 & 1,365 & 607 \\
\hline Metal Products & 56,001 & 83 & 998 & 5 & 1,417 & 276 & 15,648 & 429 & 573 & 4,180 & 3,592 \\
\hline Transportation Equipment & 128,874 & 169 & 613 & 0 & 69 & 90 & 43,993 & 21 & 3 & 14,064 & 1,314 \\
\hline Machinery \& Equipment & 307,001 & 17,834 & 549 & 94 & 117 & 6,053 & 32,119 & 1,128 & 13 & 38,411 & 1,726 \\
\hline Other Manufactures & 39,851 & 38 & 80 & 3 & 219 & 962 & 988 & 289 & 7 & 1,400 & 491 \\
\hline Elec., Gas \& Water & 2,230 & 2 & 2 & 1 & 22 & 2 & 1,445 & 5 & 0 & 2 & 117 \\
\hline Construction & 1,268 & 3 & 3 & 2 & 3 & 3 & 4 & 18 & 0 & 2 & 7 \\
\hline Trade \& Transport & 75,050 & 919 & 2,084 & 163 & 578 & 1,381 & 1,696 & 873 & 296 & 1,270 & 1,522 \\
\hline Other Private Services & 59,724 & 1,996 & 1,034 & 77 & 216 & 642 & 2,111 & 522 & 94 & 741 & 1,096 \\
\hline Government Services & 18,838 & 125 & 501 & 222 & 158 & 115 & 466 & 335 & 54 & 144 & 699 \\
\hline Total & $1,022,879$ & 22,743 & 8,025 & 782 & 3,771 & 15,017 & 171,418 & 17,004 & 2,924 & 87,739 & 38,256 \\
\hline
\end{tabular}




\begin{tabular}{|c|c|c|c|c|c|c|c|c|c|c|c|}
\hline \multirow[b]{2}{*}{ Percent } & \multirow[t]{2}{*}{ Global } & \multirow[t]{2}{*}{ Singapore } & \multirow[t]{2}{*}{ Australia } & \multirow[t]{2}{*}{ Morocco } & \multirow[t]{2}{*}{ SACU } & \multirow[t]{2}{*}{ Thailand } & \multicolumn{5}{|c|}{ FTAA } \\
\hline & & & & & & & Canada & CAC & Chile & Mexico & $\begin{array}{c}\text { South } \\
\text { America } \\
\end{array}$ \\
\hline Agriculture & 100.0 & 0.2 & 1.0 & 0.1 & 0.3 & 1.1 & 21.4 & 12.3 & 3.9 & 15.9 & 19.3 \\
\hline Mining & 100.0 & 0.0 & 0.6 & 0.1 & 0.2 & 0.0 & 24.4 & 0.9 & 0.1 & 11.9 & 18.4 \\
\hline Food, Beverages \& Tobacco & 100.0 & 0.4 & 3.1 & 0.1 & 0.5 & 5.8 & 19.3 & 4.9 & 1.9 & 6.8 & 8.4 \\
\hline Textiles & 100.0 & 0.6 & 0.8 & 0.0 & 0.5 & 1.8 & 8.4 & 8.0 & 0.0 & 12.3 & 1.7 \\
\hline Wearing Apparel & 100.0 & 0.5 & 0.1 & 0.2 & 0.4 & 3.2 & 2.7 & 14.2 & 0.0 & 10.4 & 1.6 \\
\hline Leather Products \& Footwear & 100.0 & 0.0 & 0.1 & 0.0 & 0.1 & 3.6 & 1.0 & 2.0 & 0.0 & 2.8 & 7.2 \\
\hline Wood \& Wood Products & 100.0 & 0.5 & 0.2 & 0.0 & 0.2 & 0.8 & 57.7 & 0.4 & 0.8 & 6.8 & 2.8 \\
\hline Chemicals & 100.0 & 1.1 & 0.4 & 0.0 & 0.3 & 0.9 & 20.0 & 1.1 & 0.2 & 3.6 & 5.7 \\
\hline Non-metallic Min. Products & 100.0 & 0.1 & 0.3 & 0.0 & 0.3 & 1.1 & 18.3 & 2.6 & 0.1 & 9.7 & 4.3 \\
\hline Metal Products & 100.0 & 0.1 & 1.8 & 0.0 & 2.5 & 0.5 & 27.9 & 0.8 & 1.0 & 7.5 & 6.4 \\
\hline Transportation Equipment & 100.0 & 0.1 & 0.5 & 0.0 & 0.1 & 0.1 & 34.1 & 0.0 & 0.0 & 10.9 & 1.0 \\
\hline Machinery \& Equipment & 100.0 & 5.8 & 0.2 & 0.0 & 0.0 & 2.0 & 10.5 & 0.4 & 0.0 & 12.5 & 0.6 \\
\hline Other Manufactures & 100.0 & 0.1 & 0.2 & 0.0 & 0.6 & 2.4 & 2.5 & 0.7 & 0.0 & 3.5 & 1.2 \\
\hline Elec., Gas \& Water & 100.0 & 0.1 & 0.1 & 0.0 & 1.0 & 0.1 & 64.8 & 0.2 & 0.0 & 0.1 & 5.2 \\
\hline Construction & 100.0 & 0.2 & 0.2 & 0.1 & 0.2 & 0.2 & 0.3 & 1.4 & 0.0 & 0.1 & 0.5 \\
\hline Trade \& Transport & 100.0 & 1.2 & 2.8 & 0.2 & 0.8 & 1.8 & 2.3 & 1.2 & 0.4 & 1.7 & 2.0 \\
\hline Other Private Services & 100.0 & 3.3 & 1.7 & 0.1 & 0.4 & 1.1 & 3.5 & 0.9 & 0.2 & 1.2 & 1.8 \\
\hline Government Services & 100.0 & 0.7 & 2.7 & 1.2 & 0.8 & 0.6 & 2.5 & 1.8 & 0.3 & 0.8 & 3.7 \\
\hline Total & 100.0 & 2.2 & 0.8 & 0.1 & 0.4 & 1.5 & 16.8 & 1.7 & 0.3 & 8.6 & 3.7 \\
\hline
\end{tabular}

Source: GTAP 5.4 adapted from Dimaranan and McDougall (2002). 
Table 5. Value of Japan's Sectoral Exports by Destination and Origin, 1997 (Millions of U.S. Dollars)

\begin{tabular}{|c|c|c|c|c|c|c|c|c|c|}
\hline Value & Global & Singapore & Chile & Indonesia & Korea & Malaysia & Mexico & Phlippines & Thailand \\
\hline Agriculture & 493 & 13 & 1 & 8 & 49 & 4 & 3 & 5 & 14 \\
\hline Mining & 188 & 2 & 0 & 13 & 25 & 7 & 4 & 3 & 7 \\
\hline Food, Beverages \& Tobacco & 2,803 & 131 & 3 & 25 & 200 & 41 & 6 & 57 & 118 \\
\hline Textiles & 7,581 & 177 & 2 & 245 & 543 & 130 & 22 & 126 & 186 \\
\hline Wearing Apparel & 1,054 & 14 & 1 & 4 & 50 & 5 & 5 & 4 & 7 \\
\hline Leather Products \& Footwear & 315 & 9 & 0 & 4 & 36 & 2 & 1 & 10 & 12 \\
\hline Wood \& Wood Products & 3,356 & 146 & 10 & 97 & 218 & 157 & 19 & 55 & 111 \\
\hline Chemicals & 42,360 & 1,851 & 87 & 1,239 & 4,105 & 1,117 & 283 & 640 & 1,542 \\
\hline Non-metallic Min. Products & 6,763 & 434 & 4 & 140 & 896 & 320 & 51 & 215 & 325 \\
\hline Metal Products & 29,106 & 1,638 & 26 & 1,206 & 3,307 & 1,817 & 296 & 498 & 2,063 \\
\hline Transportation Equipment & 92,470 & 1,834 & 390 & 1,961 & 730 & 1,702 & 666 & 1,156 & 2,001 \\
\hline Machinery \& Equipment & 233,236 & 14,234 & 560 & 4,865 & 15,742 & 9,136 & 2,338 & 6,335 & 8,211 \\
\hline Other Manufactures & 7,648 & 228 & 9 & 74 & 342 & 161 & 40 & 34 & 116 \\
\hline Elec., Gas \& Water & 78 & 1 & 0 & 0 & 1 & 0 & 1 & 0 & 1 \\
\hline Construction & 6,658 & 1 & 0 & 1 & 2 & 1 & 1 & 147 & 74 \\
\hline Trade \& Transport & 33,227 & 356 & 131 & 171 & 1,045 & 189 & 287 & 98 & 205 \\
\hline Other Private Services & 18,131 & 219 & 27 & 142 & 249 & 126 & 364 & 40 & 163 \\
\hline Government Services & 4,999 & 42 & 9 & 26 & 57 & 20 & 46 & 14 & 28 \\
\hline Total & 490,466 & 21,329 & 1,260 & 10,219 & 27,597 & 14,936 & 4,430 & 9,438 & 15,184 \\
\hline
\end{tabular}




\begin{tabular}{|c|c|c|c|c|c|c|c|c|c|}
\hline Percent & Global & Singapore & Chile & Indonesia & Korea & Malaysia & Mexico & Phlippines & Thailand \\
\hline Agriculture & 100.0 & 2.7 & 0.1 & 1.6 & 10.0 & 0.9 & 0.5 & 1.0 & 2.7 \\
\hline Mining & 100.0 & 1.0 & 0.2 & 6.9 & 13.1 & 3.8 & 2.1 & 1.5 & 3.5 \\
\hline Food, Beverages \& Tobacco & 100.0 & 4.7 & 0.1 & 0.9 & 7.1 & 1.5 & 0.2 & 2.0 & 4.2 \\
\hline Textiles & 100.0 & 2.3 & 0.0 & 3.2 & 7.2 & 1.7 & 0.3 & 1.7 & 2.5 \\
\hline Wearing Apparel & 100.0 & 1.3 & 0.1 & 0.4 & 4.8 & 0.5 & 0.4 & 0.4 & 0.7 \\
\hline Leather Products \& Footwear & 100.0 & 2.7 & 0.1 & 1.4 & 11.5 & 0.6 & 0.2 & 3.1 & 3.9 \\
\hline Wood \& Wood Products & 100.0 & 4.3 & 0.3 & 2.9 & 6.5 & 4.7 & 0.6 & 1.7 & 3.3 \\
\hline Chemicals & 100.0 & 4.4 & 0.2 & 2.9 & 9.7 & 2.6 & 0.7 & 1.5 & 3.6 \\
\hline Non-metallic Min. Products & 100.0 & 6.4 & 0.1 & 2.1 & 13.3 & 4.7 & 0.8 & 3.2 & 4.8 \\
\hline Metal Products & 100.0 & 5.6 & 0.1 & 4.1 & 11.4 & 6.2 & 1.0 & 1.7 & 7.1 \\
\hline Transportation Equipment & 100.0 & 2.0 & 0.4 & 2.1 & 0.8 & 1.8 & 0.7 & 1.3 & 2.2 \\
\hline Machinery \& Equipment & 100.0 & 6.1 & 0.2 & 2.1 & 6.7 & 3.9 & 1.0 & 2.7 & 3.5 \\
\hline Other Manufactures & 100.0 & 3.0 & 0.1 & 1.0 & 4.5 & 2.1 & 0.5 & 0.4 & 1.5 \\
\hline Elec., Gas \& Water & 100.0 & 1.5 & 0.2 & 0.6 & 1.7 & 0.6 & 1.0 & 0.5 & 0.9 \\
\hline Construction & 100.0 & 0.0 & 0.0 & 0.0 & 0.0 & 0.0 & 0.0 & 2.2 & 1.1 \\
\hline Trade \& Transport & 100.0 & 1.1 & 0.4 & 0.5 & 3.1 & 0.6 & 0.9 & 0.3 & 0.6 \\
\hline Other Private Services & 100.0 & 1.2 & 0.1 & 0.8 & 1.4 & 0.7 & 2.0 & 0.2 & 0.9 \\
\hline Government Services & 100.0 & 0.8 & 0.2 & 0.5 & 1.1 & 0.4 & 0.9 & 0.3 & 0.6 \\
\hline Total & 100.0 & 4.3 & 0.3 & 2.1 & 5.6 & 3.0 & 0.9 & 1.9 & 3.1 \\
\hline
\end{tabular}

Source: GTAP 5.4 adapted from Dimaranan and McDougall (2002). 
Table 6. Value of Japan's Sectoral Imports by Destination and Origin, 1997 (Millions of U.S. Dollars)

\begin{tabular}{|c|c|c|c|c|c|c|c|c|c|}
\hline Value & Global & Singapore & Chile & Indonesia & Korea & Malaysia & Mexico & Phlippines & Thailand \\
\hline Agriculture & 21,409 & 84 & 104 & 332 & 470 & 514 & 149 & 299 & 206 \\
\hline Mining & 50,163 & 3 & 1,074 & 5,304 & 33 & 1,498 & 466 & 314 & 8 \\
\hline Food, Beverages \& Tobacco & 31,690 & 166 & 797 & 1,012 & 1,321 & 387 & 209 & 257 & 2,161 \\
\hline Textiles & 10,216 & 11 & 3 & 412 & 792 & 172 & 19 & 33 & 261 \\
\hline Wearing Apparel & 12,503 & 24 & 3 & 239 & 497 & 79 & 14 & 122 & 295 \\
\hline Leather Products \& Footwear & 5,835 & 17 & 1 & 214 & 401 & 3 & 9 & 22 & 78 \\
\hline Wood \& Wood Products & 19,128 & 121 & 445 & 2,503 & 188 & 1,386 & 12 & 137 & 530 \\
\hline Chemicals & 35,097 & 872 & 40 & 650 & 2,897 & 634 & 134 & 146 & 1,005 \\
\hline Non-metallic Min. Products & 5,436 & 43 & 2 & 58 & 289 & 101 & 38 & 36 & 236 \\
\hline Metal Products & 21,098 & 193 & 465 & 576 & 2,430 & 285 & 67 & 157 & 408 \\
\hline Transportation Equipment & 17,723 & 22 & 0 & 71 & 155 & 50 & 17 & 77 & 99 \\
\hline Machinery \& Equipment & 78,030 & 5,413 & 1 & 944 & 5,064 & 4,049 & 197 & 2,755 & 3,906 \\
\hline Other Manufactures & 9,686 & 35 & 0 & 102 & 359 & 94 & 37 & 88 & 403 \\
\hline Elec., Gas \& Water & 732 & 2 & 0 & 6 & 1 & 2 & 4 & 1 & 1 \\
\hline Construction & 6,918 & 2 & 0 & 1 & 2 & 1 & 1 & 6 & 10 \\
\hline Trade \& Transport & 51,819 & 814 & 180 & 819 & 559 & 602 & 1,149 & 296 & 1,048 \\
\hline Other Private Services & 30,411 & 392 & 40 & 82 & 322 & 104 & 242 & 22 & 115 \\
\hline Government Services & 10,323 & 62 & 5 & 35 & 145 & 23 & 41 & 15 & 33 \\
\hline Total & 418,217 & 8,275 & 3,161 & 13,358 & 15,926 & 9,985 & 2,807 & 4,782 & 10,805 \\
\hline
\end{tabular}




\begin{tabular}{|c|c|c|c|c|c|c|c|c|c|}
\hline Percent & Global & Singapore & Chile & Indonesia & Korea & Malaysia & Mexico & Phlippines & Thailand \\
\hline Agriculture & 100.0 & 0.4 & 0.5 & 1.5 & 2.2 & 2.4 & 0.7 & 1.4 & 1.0 \\
\hline Mining & 100.0 & 0.0 & 2.1 & 10.6 & 0.1 & 3.0 & 0.9 & 0.6 & 0.0 \\
\hline Food, Beverages \& Tobacco & 100.0 & 0.5 & 2.5 & 3.2 & 4.2 & 1.2 & 0.7 & 0.8 & 6.8 \\
\hline Textiles & 100.0 & 0.1 & 0.0 & 4.0 & 7.8 & 1.7 & 0.2 & 0.3 & 2.6 \\
\hline Wearing Apparel & 100.0 & 0.2 & 0.0 & 1.9 & 4.0 & 0.6 & 0.1 & 1.0 & 2.4 \\
\hline Leather Products \& Footwear & 100.0 & 0.3 & 0.0 & 3.7 & 6.9 & 0.1 & 0.2 & 0.4 & 1.3 \\
\hline Wood \& Wood Products & 100.0 & 0.6 & 2.3 & 13.1 & 1.0 & 7.2 & 0.1 & 0.7 & 2.8 \\
\hline Chemicals & 100.0 & 2.5 & 0.1 & 1.9 & 8.3 & 1.8 & 0.4 & 0.4 & 2.9 \\
\hline Non-metallic Min. Products & 100.0 & 0.8 & 0.0 & 1.1 & 5.3 & 1.9 & 0.7 & 0.7 & 4.3 \\
\hline Metal Products & 100.0 & 0.9 & 2.2 & 2.7 & 11.5 & 1.3 & 0.3 & 0.7 & 1.9 \\
\hline Transportation Equipment & 100.0 & 0.1 & 0.0 & 0.4 & 0.9 & 0.3 & 0.1 & 0.4 & 0.6 \\
\hline Machinery \& Equipment & 100.0 & 6.9 & 0.0 & 1.2 & 6.5 & 5.2 & 0.3 & 3.5 & 5.0 \\
\hline Other Manufactures & 100.0 & 0.4 & 0.0 & 1.1 & 3.7 & 1.0 & 0.4 & 0.9 & 4.2 \\
\hline Elec., Gas \& Water & 100.0 & 0.2 & 0.1 & 0.8 & 0.1 & 0.3 & 0.5 & 0.1 & 0.2 \\
\hline Construction & 100.0 & 0.0 & 0.0 & 0.0 & 0.0 & 0.0 & 0.0 & 0.1 & 0.1 \\
\hline Trade \& Transport & 100.0 & 1.6 & 0.3 & 1.6 & 1.1 & 1.2 & 2.2 & 0.6 & 2.0 \\
\hline Other Private Services & 100.0 & 1.3 & 0.1 & 0.3 & 1.1 & 0.3 & 0.8 & 0.1 & 0.4 \\
\hline Government Services & 100.0 & 0.6 & 0.0 & 0.3 & 1.4 & 0.2 & 0.4 & 0.1 & 0.3 \\
\hline Total & 100.0 & 2.0 & 0.8 & 3.2 & 3.8 & 2.4 & 0.7 & 1.1 & 2.6 \\
\hline
\end{tabular}

Source: GTAP 5.4 adapted from Dimaranan and McDougall (2002). 
Table 7. Employment by Sector, 1997: United States, Japan and FTA Partners

(Number of Workers and Percent of Employment)

\begin{tabular}{|c|c|c|c|c|c|c|c|c|c|c|c|c|c|c|c|c|}
\hline \multirow[b]{2}{*}{ Workers (thousand) } & \multirow[b]{2}{*}{$\begin{array}{l}\text { United } \\
\text { States }\end{array}$} & \multirow[b]{2}{*}{ Japan } & \multirow[b]{2}{*}{ Korea } & \multirow[b]{2}{*}{ Singapore } & \multirow[b]{2}{*}{ Indonesia } & \multirow[b]{2}{*}{ Malaysia } & \multirow[b]{2}{*}{ Phlippines } & \multirow[b]{2}{*}{ Thailand } & \multirow[b]{2}{*}{ Australia } & \multirow[b]{2}{*}{ Morocco } & \multirow[b]{2}{*}{ SACU } & \multicolumn{5}{|c|}{ FTAA } \\
\hline & & & & & & & & & & & & Chile & Canada & CAC & Mexico & $\begin{array}{c}\text { South } \\
\text { America }\end{array}$ \\
\hline Agriculture & 3,538 & 3,518 & 2,385 & 5 & 35,850 & 1,481 & 11,262 & 16,696 & 431 & 552 & 4,686 & 776 & 1,058 & 4,074 & 9,023 & 18,636 \\
\hline Mining & 634 & 70 & 26 & 1 & 897 & 39 & 124 & 47 & 75 & 93 & 308 & 88 & 365 & 97 & 108 & 1,021 \\
\hline Food, Beverages \& Tobacco & 2,145 & 1,789 & 317 & 17 & 2,149 & 153 & 609 & 622 & 208 & 568 & 201 & 277 & 544 & 725 & 1,556 & 3,657 \\
\hline Textiles & 949 & 630 & 384 & 2 & 1,683 & 67 & 190 & 710 & 41 & 383 & 68 & 46 & 143 & 179 & 495 & 1,119 \\
\hline Wearing Apparel & 797 & 460 & 260 & 9 & 1,050 & 92 & 459 & 1,241 & 45 & 653 & 117 & 40 & 160 & 513 & 162 & 1,104 \\
\hline Leather Products \& Footwear & 111 & 106 & 96 & 1 & 875 & 7 & 65 & 80 & 13 & 84 & 30 & 28 & 32 & 64 & 172 & 456 \\
\hline Wood \& Wood Products & 2,218 & 1,725 & 363 & 36 & 1,938 & 352 & 274 & 234 & 215 & 158 & 201 & 134 & 902 & 207 & 586 & 1,587 \\
\hline Chemicals & 2,667 & 1,431 & 490 & 45 & 1,295 & 254 & 286 & 276 & 113 & 264 & 162 & 121 & 462 & 261 & 1,042 & 2,172 \\
\hline Non-metallic Min. Products & 690 & 592 & 187 & 8 & 502 & 93 & 106 & 208 & 48 & 220 & 73 & 35 & 116 & 88 & 325 & 887 \\
\hline Metal Products & 3,054 & 1,760 & 489 & 42 & 570 & 152 & 175 & 363 & 189 & 140 & 202 & 107 & 553 & 118 & 493 & 1,336 \\
\hline Transportation Equipment & 2,244 & 1,292 & 543 & 41 & 354 & 83 & 75 & 135 & 97 & 66 & 84 & 26 & 534 & 28 & 583 & 523 \\
\hline Machinery \& Equipment & 5,441 & 4,425 & 1,276 & 209 & 607 & 718 & 434 & 305 & 151 & 113 & 175 & 44 & 719 & 123 & 790 & 859 \\
\hline Other Manufactures & 519 & 287 & 78 & 4 & 193 & 31 & 80 & 119 & 16 & 3 & 24 & 4 & 69 & 34 & 62 & 169 \\
\hline Elec., Gas \& Water & 1,493 & 362 & 77 & 12 & 233 & 51 & 139 & 178 & 66 & 97 & 131 & 31 & 256 & 138 & 188 & 213 \\
\hline Construction & 8,302 & 6,886 & 2,004 & 126 & 4,200 & 793 & 1,641 & 2,021 & 580 & 959 & 1,362 & 489 & 1,478 & 982 & 1,759 & 6,974 \\
\hline Trade \& Transport & 34,466 & 18,968 & 6,967 & 609 & 21,360 & 2,001 & 5,989 & 5,583 & 2,674 & 2,757 & 3,024 & 1,377 & 8,541 & 3,800 & 9,550 & 23,466 \\
\hline Other Private Services & 14,768 & 5,780 & 1,900 & 274 & 657 & 447 & 680 & 882 & 1,197 & 244 & 1,354 & 377 & 3,906 & 405 & 1,513 & 3,661 \\
\hline Government Services & 45,521 & 15,500 & 3,265 & 389 & 12,637 & 1,755 & 5,297 & 3,461 & 2,229 & 3,319 & 6,304 & 1,382 & 8,043 & 3,925 & 8,951 & 35,062 \\
\hline Total & 129,557 & 65,580 & 21,106 & 1,831 & 87,050 & 8,569 & 27,888 & 33,162 & 8,387 & 10,675 & 18,508 & 5,380 & 27,880 & 15,761 & 37,360 & 102,901 \\
\hline
\end{tabular}




\begin{tabular}{|c|c|c|c|c|c|c|c|c|c|c|c|c|c|c|c|c|}
\hline \multirow[b]{2}{*}{ Percent } & \multirow[b]{2}{*}{$\begin{array}{l}\text { United } \\
\text { States }\end{array}$} & \multirow[b]{2}{*}{ Japan } & \multirow[b]{2}{*}{ Korea } & \multirow[b]{2}{*}{ Singapore } & \multirow[b]{2}{*}{ Indonesia } & \multirow[b]{2}{*}{ Malaysia } & \multirow[b]{2}{*}{ Phlippines } & \multirow[b]{2}{*}{ Thailand } & \multirow[b]{2}{*}{ Australia } & \multirow[b]{2}{*}{ Morocco } & \multirow[b]{2}{*}{ SACU } & \multicolumn{5}{|c|}{ FTAA } \\
\hline & & & & & & & & & & & & Chile & Canada & CAC & Mexico & $\begin{array}{c}\text { South } \\
\text { America }\end{array}$ \\
\hline Agriculture & 2.7 & 5.4 & 11.3 & 0.3 & 41.2 & 17.3 & 40.4 & 50.3 & 5.1 & 5.2 & 25.3 & 14.4 & 3.8 & 25.8 & 24.2 & 18.1 \\
\hline $\begin{array}{l}\text { Mining } \\
\text { Food, Beverages \& }\end{array}$ & 0.5 & 0.1 & 0.1 & 0.0 & 1.0 & 0.4 & 0.4 & 0.1 & 0.9 & 0.9 & 1.7 & 1.6 & 1.3 & 0.6 & 0.3 & 1.0 \\
\hline Tobacco & 1.7 & 2.7 & 1.5 & 0.9 & 2.5 & 1.8 & 2.2 & 1.9 & 2.5 & 5.3 & 1.1 & 5.2 & 2.0 & 4.6 & 4.2 & 3.6 \\
\hline Textiles & 0.7 & 1.0 & 1.8 & 0.1 & 1.9 & 0.8 & 0.7 & 2.1 & 0.5 & 3.6 & 0.4 & 0.8 & 0.5 & 1.1 & 1.3 & 1.1 \\
\hline $\begin{array}{l}\text { Wearing Apparel } \\
\text { Leather Products \& }\end{array}$ & 0.6 & 0.7 & 1.2 & 0.5 & 1.2 & 1.1 & 1.6 & 3.7 & 0.5 & 6.1 & 0.6 & 0.7 & 0.6 & 3.3 & 0.4 & 1.1 \\
\hline Footwear & 0.1 & 0.2 & 0.5 & 0.1 & 1.0 & 0.1 & 0.2 & 0.2 & 0.1 & 0.8 & 0.2 & 0.5 & 0.1 & 0.4 & 0.5 & 0.4 \\
\hline Wood \& Wood Products & 1.7 & 2.6 & 1.7 & 1.9 & 2.2 & 4.1 & 1.0 & 0.7 & 2.6 & 1.5 & 1.1 & 2.5 & 3.2 & 1.3 & 1.6 & 1.5 \\
\hline Chemicals & 2.1 & 2.2 & 2.3 & 2.5 & 1.5 & 3.0 & 1.0 & 0.8 & 1.3 & 2.5 & 0.9 & 2.2 & 1.7 & 1.7 & 2.8 & 2.1 \\
\hline Non-metallic Min. Products & 0.5 & 0.9 & 0.9 & 0.4 & 0.6 & 1.1 & 0.4 & 0.6 & 0.6 & 2.1 & 0.4 & 0.6 & 0.4 & 0.6 & 0.9 & 0.9 \\
\hline Metal Products & 2.4 & 2.7 & 2.3 & 2.3 & 0.7 & 1.8 & 0.6 & 1.1 & 2.3 & 1.3 & 1.1 & 2.0 & 2.0 & 0.7 & 1.3 & 1.3 \\
\hline Transportation Equipment & 1.7 & 2.0 & 2.6 & 2.2 & 0.4 & 1.0 & 0.3 & 0.4 & 1.2 & 0.6 & 0.5 & 0.5 & 1.9 & 0.2 & 1.6 & 0.5 \\
\hline Machinery \& Equipment & 4.2 & 6.7 & 6.0 & 11.4 & 0.7 & 8.4 & 1.6 & 0.9 & 1.8 & 1.1 & 0.9 & 0.8 & 2.6 & 0.8 & 2.1 & 0.8 \\
\hline Other Manufactures & 0.4 & 0.4 & 0.4 & 0.2 & 0.2 & 0.4 & 0.3 & 0.4 & 0.2 & 0.0 & 0.1 & 0.1 & 0.2 & 0.2 & 0.2 & 0.2 \\
\hline Elec., Gas \& Water & 1.2 & 0.6 & 0.4 & 0.7 & 0.3 & 0.6 & 0.5 & 0.5 & 0.8 & 0.9 & 0.7 & 0.6 & 0.9 & 0.9 & 0.5 & 0.2 \\
\hline Construction & 6.4 & 10.5 & 9.5 & 6.9 & 4.8 & 9.3 & 5.9 & 6.1 & 6.9 & 9.0 & 7.4 & 9.1 & 5.3 & 6.2 & 4.7 & 6.8 \\
\hline Trade \& Transport & 26.6 & 28.9 & 33.0 & 33.3 & 24.5 & 23.4 & 21.5 & 16.8 & 31.9 & 25.8 & 16.3 & 25.6 & 30.6 & 24.1 & 25.6 & 22.8 \\
\hline Other Private Services & 11.4 & 8.8 & 9.0 & 15.0 & 0.8 & 5.2 & 2.4 & 2.7 & 14.3 & 2.3 & 7.3 & 7.0 & 14.0 & 2.6 & 4.1 & 3.6 \\
\hline Government Services & 35.1 & 23.6 & 15.5 & 21.3 & 14.5 & 20.5 & 19.0 & 10.4 & 26.6 & 31.1 & 34.1 & 25.7 & 28.8 & 24.9 & 24.0 & 34.1 \\
\hline Total & 100.0 & 100.0 & 100.0 & 100.0 & 100.0 & 100.0 & 100.0 & 100.0 & 100.0 & 100.0 & 100.0 & 100.0 & 100.0 & 100.0 & 100.0 & 100.0 \\
\hline
\end{tabular}

Sources: ILO webiste (2003); Taiwan government website (2003); UNIDO (2003); and World Bank (2003). 
Table 8. Global Welfare Effects of Bilateral Negotiating Options for the United States

(Billions of Dollars and Percent of

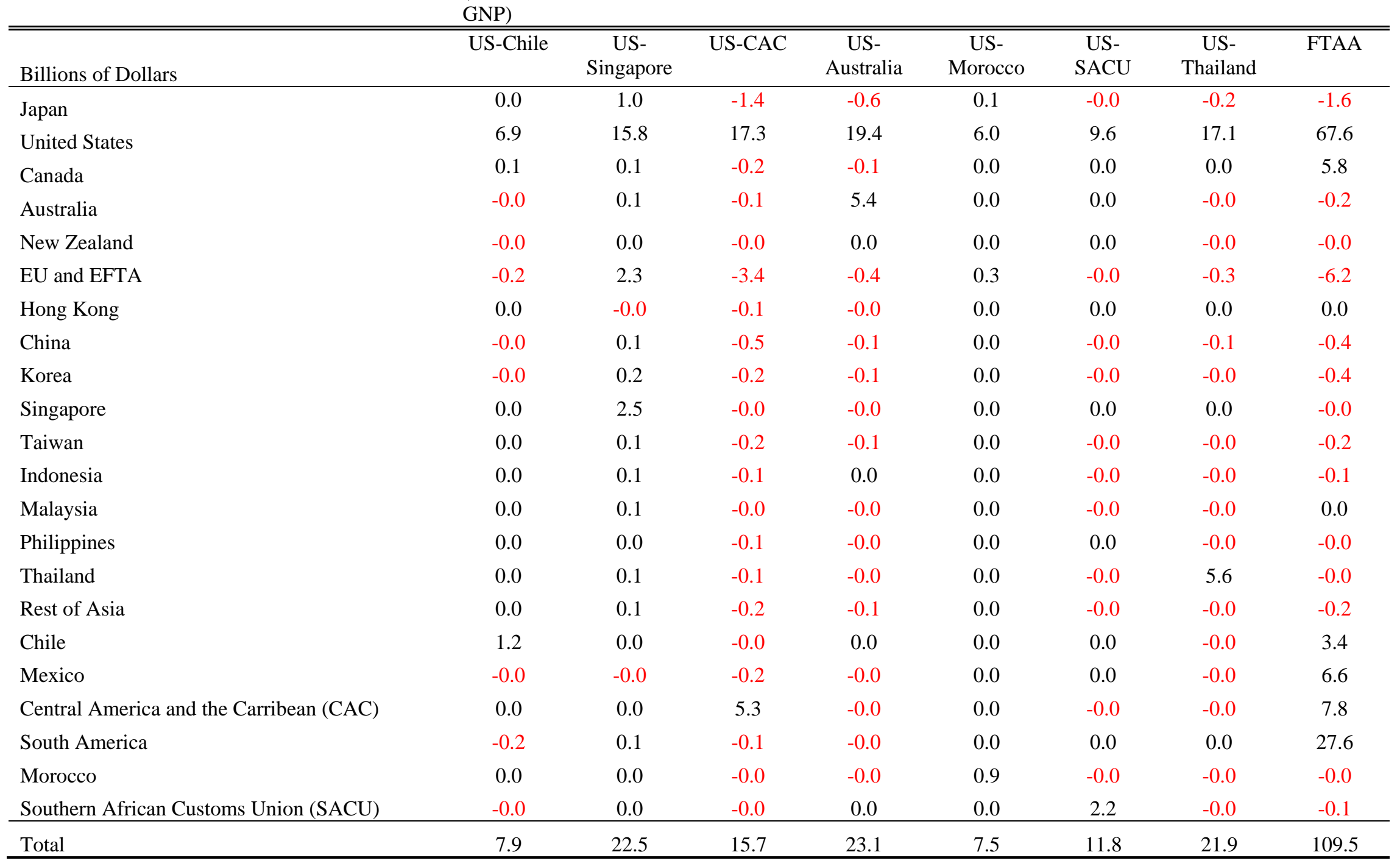




\begin{tabular}{|c|c|c|c|c|c|c|c|c|}
\hline Percent & US-Chile & $\begin{array}{c}\text { US- } \\
\text { Singapore }\end{array}$ & US-CAC & $\begin{array}{c}\text { US- } \\
\text { Australia } \\
\end{array}$ & $\begin{array}{c}\text { US- } \\
\text { Morocco } \\
\end{array}$ & US-SACU & $\begin{array}{c}\text { US- } \\
\text { Thailand } \\
\end{array}$ & $\overline{\text { FTAA }}$ \\
\hline Japan & 0.0 & 0.0 & -0.0 & -0.0 & 0.0 & 0.0 & -0.0 & -0.0 \\
\hline United States & 0.1 & 0.2 & 0.2 & 0.2 & 0.1 & 0.1 & 0.2 & 0.7 \\
\hline Canada & 0.0 & 0.0 & -0.0 & 0.0 & 0.0 & 0.0 & 0.0 & 0.7 \\
\hline Australia & 0.0 & 0.0 & -0.0 & 1.1 & 0.0 & 0.0 & -0.0 & -0.0 \\
\hline New Zealand & 0.0 & 0.0 & -0.0 & 0.0 & 0.0 & 0.0 & 0.0 & -0.1 \\
\hline EU and EFTA & 0.0 & 0.0 & -0.0 & 0.0 & 0.0 & 0.0 & -0.0 & -0.1 \\
\hline Hong Kong & 0.0 & -0.0 & -0.0 & -0.0 & 0.0 & 0.0 & 0.0 & 0.0 \\
\hline China & 0.0 & 0.0 & -0.1 & -0.0 & 0.0 & 0.0 & -0.0 & -0.0 \\
\hline Korea & -0.0 & 0.0 & -0.0 & -0.0 & 0.0 & 0.0 & -0.0 & -0.1 \\
\hline Singapore & 0.0 & 2.6 & -0.0 & -0.0 & 0.0 & 0.0 & 0.0 & 0.0 \\
\hline Taiwan & 0.0 & 0.0 & -0.1 & -0.0 & 0.0 & 0.0 & -0.0 & -0.1 \\
\hline Indonesia & 0.0 & 0.0 & -0.1 & 0.0 & 0.0 & 0.0 & -0.0 & -0.1 \\
\hline Malaysia & 0.0 & 0.1 & 0.0 & -0.0 & 0.0 & 0.0 & -0.0 & 0.0 \\
\hline Philippines & 0.0 & 0.0 & -0.1 & -0.0 & 0.0 & 0.0 & -0.0 & -0.0 \\
\hline Thailand & 0.0 & 0.0 & -0.0 & -0.0 & 0.0 & 0.0 & 2.8 & -0.0 \\
\hline Rest of Asia & 0.0 & 0.0 & -0.0 & -0.0 & 0.0 & 0.0 & -0.0 & -0.0 \\
\hline Chile & 1.3 & 0.0 & -0.0 & 0.0 & 0.0 & 0.0 & -0.0 & 3.6 \\
\hline Mexico & 0.0 & 0.0 & -0.0 & 0.0 & 0.0 & 0.0 & 0.0 & 1.3 \\
\hline Central America and the Carribean (CAC) & 0.0 & 0.0 & 4.4 & -0.0 & 0.0 & 0.0 & -0.0 & 6.5 \\
\hline South America & -0.0 & 0.0 & 0.0 & 0.0 & 0.0 & 0.0 & 0.0 & 1.5 \\
\hline Morocco & 0.0 & 0.0 & -0.0 & 0.0 & 2.0 & 0.0 & 0.0 & -0.0 \\
\hline Southern African Customs Union (SACU) & -0.0 & 0.0 & -0.0 & 0.0 & 0.0 & 1.2 & -0.0 & -0.0 \\
\hline
\end{tabular}


Table 9. Sectoral Employment Effects of Bilateral Negotiating Options for the United States

(Number of Workers and Percent of

Employment)

\begin{tabular}{lrrrrrrr}
\hline \hline & US-Chile & $\begin{array}{c}\text { US- } \\
\text { Sumbapore }\end{array}$ & US-CAC & $\begin{array}{c}\text { US- } \\
\text { Australia }\end{array}$ & $\begin{array}{c}\text { US- } \\
\text { Morocco }\end{array}$ & $\begin{array}{c}\text { US- } \\
\text { SACU }\end{array}$ & $\begin{array}{c}\text { US- } \\
\text { Thailand }\end{array}$ \\
\hline Agriculture & $(1,427)$ & 1,335 & 2,173 & 94 & 1,314 & 973 & 2,458 \\
Mining & $(58)$ & 358 & 596 & 504 & $(44)$ & 27 & 129 \\
Food, Beverages \& Tobacco & $(548)$ & 52 & 495 & $(756)$ & 542 & 353 & $(1,077)$ \\
Textiles & 73 & $(102)$ & $(5,133)$ & 810 & $(32)$ & $(109)$ & $(1,230)$ \\
Wearing Apparel & $(118)$ & $(227)$ & $(14,006)$ & 619 & $(129)$ & $(211)$ & $(2,530)$ \\
Leather products \& Footwear & $(28)$ & 112 & 1,512 & 207 & $(8)$ & 202 & $(395)$ \\
Wood \& Wood Products & $(16)$ & 143 & 1,761 & 394 & $(10)$ & 163 & 41 \\
Chemicals & 355 & 617 & 2,667 & 1,555 & $(55)$ & 127 & 1,384 \\
Non-metallic Min. Products & 86 & 210 & 666 & 539 & 29 & 76 & 62 \\
Metal Products & 87 & 1,358 & 2,218 & 1,957 & $(138)$ & 33 & 1,175 \\
Transportation Equipment & 321 & 959 & 1,069 & 1,741 & $(50)$ & 369 & 351 \\
Machinery \& Equipment & 1,769 & 5,309 & 3,626 & 6,229 & $(367)$ & 1,230 & 2,054 \\
Other Manufactures & 48 & 526 & 1,558 & 653 & $(52)$ & 77 & $(784)$ \\
Elec., Gas \& Water & $(30)$ & $(56)$ & 156 & 15 & 2 & 13 & $(10)$ \\
Construction & $(5)$ & $(519)$ & 31 & $(257)$ & $(57)$ & $(13)$ & 16 \\
Trade \& Transport & $(849)$ & $(4,192)$ & 640 & $(11,719)$ & $(1,140)$ & $(2,101)$ & $(4,272)$ \\
Other Private Services & $(42)$ & $(4,255)$ & 1,362 & $(2,188)$ & $(194)$ & 11 & 932 \\
Government Services & 383 & $(1,628)$ & $(1,390)$ & $(398)$ & 389 & $(1,221)$ & 1,696
\end{tabular}




\begin{tabular}{lrrrrrrr}
\hline & US-Chile & $\begin{array}{c}\text { US- } \\
\text { Singapore }\end{array}$ & US-CAC & $\begin{array}{c}\text { US- } \\
\text { Australia }\end{array}$ & $\begin{array}{c}\text { US- } \\
\text { Morocco }\end{array}$ & $\begin{array}{c}\text { US- } \\
\text { SACU }\end{array}$ & $\begin{array}{c}\text { US- } \\
\text { Thailand }\end{array}$ \\
\hline Agriculture & -0.0 & 0.0 & 0.1 & 0.0 & 0.0 & 0.0 & 0.1 \\
Mining & -0.0 & 0.1 & 0.1 & 0.1 & -0.0 & 0.0 & 0.0 \\
Food, Beverages \& Tobacco & -0.0 & 0.0 & 0.0 & -0.0 & 0.0 & 0.0 & -0.1 \\
Textiles & 0.0 & -0.0 & -0.6 & 0.1 & 0.0 & -0.0 & -0.1 \\
Wearing Apparel & -0.0 & -0.0 & -1.8 & 0.1 & -0.0 & -0.0 & -0.3 \\
Leather products \& Footwear & -0.0 & 0.1 & 1.5 & 0.2 & -0.0 & 0.2 & -0.4 \\
Wood \& Wood Products & 0.0 & 0.0 & 0.1 & 0.0 & 0.0 & 0.0 & 0.0 \\
Chemicals & 0.0 & 0.0 & 0.1 & 0.1 & 0.0 & 0.0 & 0.1 \\
Non-metallic Min. Products & 0.0 & 0.0 & 0.1 & 0.1 & 0.0 & 0.0 & 0.0 \\
Metal Products & 0.0 & 0.0 & 0.1 & 0.1 & 0.0 & 0.0 & 0.0 \\
Transportation Equipment & 0.0 & 0.0 & 0.1 & 0.1 & 0.0 & 0.0 & 0.0 \\
Machinery \& Equipment & 0.0 & 0.1 & 0.1 & 0.1 & -0.0 & 0.0 & 0.0 \\
Other Manufactures & 0.0 & 0.1 & 0.3 & 0.1 & -0.0 & 0.0 & -0.2 \\
Elec., Gas \& Water & 0.0 & 0.0 & 0.0 & 0.0 & 0.0 & 0.0 & 0.0 \\
Construction & 0.0 & -0.0 & 0.0 & 0.0 & 0.0 & 0.0 & 0.0 \\
Trade \& Transport & 0.0 & -0.0 & 0.0 & -0.0 & 0.0 & -0.0 & -0.0 \\
Other Private Services & 0.0 & -0.0 & 0.0 & -0.0 & 0.0 & 0.0 & 0.0 \\
Government Services & 0.0 & 0.0 & 0.0 & 0.0 & 0.0 & 0.0 & 0.0 \\
\hline \hline
\end{tabular}


Table 10. Sectoral Employment Effects for the US FTA Partner Countries

(Number of Workers and Percent of

Employment)

\begin{tabular}{|c|c|c|c|c|c|c|c|}
\hline Number of Workers & US-Chile & $\begin{array}{c}\text { US- } \\
\text { Singapore }\end{array}$ & US-CAC & $\begin{array}{c}\text { US- } \\
\text { Australia }\end{array}$ & $\begin{array}{c}\text { US- } \\
\text { Morocco }\end{array}$ & $\begin{array}{c}\text { US- } \\
\text { SACU }\end{array}$ & $\begin{array}{c}\text { US- } \\
\text { Thailand }\end{array}$ \\
\hline Agriculture & 9,652 & $(27)$ & $(23,731)$ & $(300)$ & $(3,124)$ & $(6,495)$ & $(70,515)$ \\
\hline Mining & 811 & (20) & $(12,650)$ & $(1,390)$ & 992 & $(961)$ & $(1,468)$ \\
\hline Food, Beverages \& Tobacco & 1,852 & 29 & $(14,061)$ & 564 & $(9,562)$ & (820) & 3,294 \\
\hline Textiles & $(255)$ & 115 & 53,741 & $(244)$ & 5,431 & 799 & 23,608 \\
\hline Wearing Apparel & (90) & 1,476 & 230,663 & $(145)$ & 8,580 & 14,668 & 62,579 \\
\hline Leather products \& Footwear & 31 & (7) & 9,518 & $(121)$ & $(376)$ & $(145)$ & 6,806 \\
\hline Wood \& Wood Products & $(118)$ & (396) & $(18,415)$ & $(648)$ & 236 & $(801)$ & $(1,692)$ \\
\hline Chemicals & $(1,677)$ & $(1,123)$ & $(19,202)$ & $(1,612)$ & 534 & $(427)$ & $(6,524)$ \\
\hline Non-metallic Min. Products & $(273)$ & $(105)$ & $(6,720)$ & $(437)$ & (995) & $(224)$ & $(1,545)$ \\
\hline Metal Products & 997 & $(1,178)$ & $(11,865)$ & $(2,912)$ & 889 & (999) & $(5,548)$ \\
\hline Transportation Equipment & $(747)$ & $(410)$ & $(2,310)$ & $(1,196)$ & (353) & (694) & $(1,324)$ \\
\hline Machinery \& Equipment & $(2,171)$ & $(6,944)$ & $(12,126)$ & $(3,490)$ & 963 & $(2,068)$ & 1,106 \\
\hline Other Manufactures & (81) & (64) & $(2,361)$ & $(390)$ & 2 & $(236)$ & 2,025 \\
\hline Elec., Gas \& Water & 64 & 34 & (518) & (67) & 113 & $(261)$ & 116 \\
\hline Construction & $(528)$ & 251 & $(13,873)$ & (599) & $(1,097)$ & $(1,185)$ & $(2,983)$ \\
\hline Trade \& Transport & 732 & 4,673 & $(71,515)$ & 11,593 & 13,729 & 1,046 & 29,809 \\
\hline Other Private Services & (38) & 4,283 & $(11,273)$ & 3,160 & 207 & $(1,233)$ & $(5,628)$ \\
\hline Government Services & $(8,161)$ & $(588)$ & $(73,302)$ & $(1,764)$ & $(16,168)$ & 35 & $(32,116)$ \\
\hline
\end{tabular}




\begin{tabular}{lrrrrrrr}
\hline & US-Chile & $\begin{array}{c}\text { US- } \\
\text { Singapore }\end{array}$ & US-CAC & $\begin{array}{c}\text { US- } \\
\text { Australia }\end{array}$ & $\begin{array}{c}\text { US- } \\
\text { Morocco }\end{array}$ & $\begin{array}{c}\text { US- } \\
\text { SACU }\end{array}$ & $\begin{array}{c}\text { US- } \\
\text { Thailand }\end{array}$ \\
\hline Agriculture & 1.2 & -0.5 & -0.6 & -0.1 & -0.6 & -0.1 & -0.4 \\
Mining & 1.0 & -3.1 & -13.6 & -1.9 & 1.1 & -0.3 & -3.3 \\
Food, Beverages \& Tobacco & 0.6 & 0.2 & -1.9 & 0.3 & -1.7 & -0.4 & 0.5 \\
Textiles & -0.6 & 5.8 & 27.9 & -0.6 & 1.3 & 1.2 & 3.5 \\
Wearing Apparel & -0.2 & 15.8 & 42.2 & -0.4 & 1.2 & 12.8 & 5.2 \\
Leather products \& Footwear & 0.1 & -0.5 & 14.6 & -1.0 & -0.5 & -0.5 & 8.7 \\
Wood \& Wood Products & -0.1 & -1.1 & -9.0 & -0.3 & 0.2 & -0.4 & -0.8 \\
Chemicals & -1.4 & -2.4 & -7.3 & -1.4 & 0.2 & -0.3 & -2.5 \\
Non-metallic Min. Products & -0.8 & -1.3 & -7.8 & -0.9 & -0.5 & -0.3 & -0.8 \\
Metal Products & 1.0 & -2.8 & -10.2 & -1.5 & 0.7 & -0.5 & -1.7 \\
Transportation Equipment & -2.9 & -1.0 & -8.5 & -1.3 & -0.6 & -0.8 & -1.0 \\
Machinery \& Equipment & -5.1 & -3.4 & -10.0 & -2.3 & 0.9 & -1.2 & 0.4 \\
Other Manufactures & -2.3 & -1.6 & -6.9 & -2.4 & 0.1 & -1.0 & 1.8 \\
Elec., Gas \& Water & 0.2 & 0.3 & -0.4 & -0.1 & 0.1 & -0.2 & 0.1 \\
Construction & -0.1 & 0.2 & -1.4 & -0.1 & -0.1 & -0.1 & -0.2 \\
Trade \& Transport & 0.1 & 0.8 & -1.9 & 0.4 & 0.5 & 0.0 & 0.6 \\
Other Private Services & -0.0 & 1.6 & -2.8 & 0.3 & 0.1 & -0.1 & -0.7 \\
Government Services & -0.6 & -0.2 & -1.9 & -0.1 & -0.5 & 0.0 & -1.0 \\
\hline \hline
\end{tabular}


Table 11. Sectoral Employment Effects for the FTAA Member Countries

(Number of Workers and Percent of

Employment)

\begin{tabular}{lrrrrrr}
\hline \hline & United & Canada & CAC & Chile & Mexico & $\begin{array}{c}\text { South } \\
\text { America }\end{array}$ \\
Number of Workers & \multicolumn{1}{c}{ States } & & & & & \\
\hline Agriculture & $(12,460)$ & 1,478 & $(39,042)$ & 14,744 & $(20,701)$ & 202,605 \\
Mining & $(3,251)$ & $(1,505)$ & $(19,685)$ & $(2,486)$ & $(553)$ & 29,499 \\
Food, Beverages \& Tobacco & $(3,452)$ & $(3,049)$ & $(18,987)$ & 1,953 & $(3,658)$ & 16,172 \\
Textiles & $(6,028)$ & $(2,060)$ & 57,999 & 206 & $(2,251)$ & $(2,133)$ \\
Wearing Apparel & $(16,804)$ & $(2,089)$ & 244,675 & $(163)$ & $(3,687)$ & 818 \\
Leather products \& Footwear & 620 & $(650)$ & 11,090 & 301 & $(1,000)$ & 10,500 \\
Wood \& Wood Products & 2,502 & $(166)$ & $(19,314)$ & 561 & 538 & $(6,481)$ \\
Chemicals & 2,883 & $(1,014)$ & $(16,078)$ & $(3,018)$ & 1,334 & $(393)$ \\
Non-metallic Min. Products & 957 & $(52)$ & $(7,194)$ & $(749)$ & 1,372 & $(2,081)$ \\
Metal Products & 2,024 & $(151)$ & $(10,672)$ & 3,512 & 1,782 & $(3,014)$ \\
Transportation Equipment & 2,970 & 5,206 & $(2,171)$ & 114 & 16,633 & $(7,730)$ \\
Machinery \& Equipment & 21,830 & 2,450 & $(8,320)$ & 1,611 & 2,489 & $(20,176)$ \\
Other Manufactures & 2,148 & $(149)$ & $(1,828)$ & $(20)$ & $(177)$ & $(532)$ \\
Elec., Gas \& Water & $(228)$ & $(81)$ & $(410)$ & 293 & 36 & 179 \\
Construction & $(88)$ & $(39)$ & $(14,623)$ & $(1,306)$ & 622 & $(11,433)$ \\
Trade \& Transport & 1,991 & 2,952 & $(62,175)$ & $(2,705)$ & 9,799 & $(74,080)$ \\
Other Private Services & 2,788 & 229 & $(11,146)$ & $(154)$ & $(2,190)$ & $(4,712)$ \\
Government Services & 1,597 & $(1,309)$ & $(82,120)$ & $(12,693)$ & $(387)$ & $(127,009)$
\end{tabular}




\begin{tabular}{lrrrrrr}
\hline & $\begin{array}{c}\text { United } \\
\text { States }\end{array}$ & Canada & CAC & Chile & Mexico & $\begin{array}{c}\text { South } \\
\text { America }\end{array}$ \\
\hline Agriculture & -0.3 & 0.1 & -1.0 & 1.9 & -0.2 & 1.1 \\
Mining & -0.5 & -0.4 & -21.2 & -2.9 & -0.5 & 2.9 \\
Food, Beverages \& Tobacco & -0.2 & -0.6 & -2.5 & 0.7 & -0.2 & 0.4 \\
Textiles & -0.6 & -1.5 & 30.1 & 0.5 & -0.5 & -0.2 \\
Wearing Apparel & -2.1 & -1.3 & 44.8 & -0.4 & -2.3 & 0.1 \\
Leather products \& Footwear & 0.6 & -2.2 & 17.0 & 1.1 & -0.6 & 2.4 \\
Wood \& Wood Products & 0.1 & -0.0 & -9.4 & 0.4 & 0.1 & -0.4 \\
Chemicals & 0.1 & -0.2 & -6.1 & -2.5 & 0.1 & -0.0 \\
Non-metallic Min. Products & 0.1 & -0.0 & -8.3 & -2.2 & 0.4 & -0.2 \\
Metal Products & 0.1 & -0.0 & -9.2 & 3.4 & 0.4 & -0.2 \\
Transportation Equipment & 0.1 & 1.0 & -8.0 & 0.4 & 2.8 & -1.5 \\
Machinery \& Equipment & 0.4 & 0.3 & -6.8 & 3.8 & 0.3 & -2.4 \\
Other Manufactures & 0.4 & -0.2 & -5.4 & -0.6 & -0.3 & -0.3 \\
Elec., Gas \& Water & -0.0 & -0.0 & -0.3 & 1.0 & 0.0 & 0.1 \\
Construction & -0.0 & -0.0 & -1.5 & -0.3 & 0.0 & -0.2 \\
Trade \& Transport & 0.0 & 0.0 & -1.6 & -0.2 & 0.1 & -0.3 \\
Other Private Services & 0.0 & 0.0 & -2.8 & -0.0 & -0.1 & -0.1 \\
Government Services & 0.0 & -0.0 & -2.1 & -0.9 & -0.0 & -0.4 \\
\hline \hline
\end{tabular}


Table 12. Global Welfare Effects of Bilateral Negotiating Options for Japan

(Billions of Dollars and Percent

$$
\text { GNP) }
$$

\begin{tabular}{|c|c|c|c|c|c|c|c|c|}
\hline Billions of Dollars & $\begin{array}{c}\text { Japan- } \\
\text { Singapore }\end{array}$ & $\begin{array}{c}\text { Japan- } \\
\text { Chile }\end{array}$ & $\begin{array}{c}\text { Japan- } \\
\text { Indonesia }\end{array}$ & $\begin{array}{l}\text { Japan- } \\
\text { Korea }\end{array}$ & $\begin{array}{c}\text { Japan- } \\
\text { Malaysia }\end{array}$ & $\begin{array}{l}\text { Japan- } \\
\text { Mexico }\end{array}$ & $\begin{array}{c}\text { Japan- } \\
\text { Philippines }\end{array}$ & $\begin{array}{c}\text { Japan- } \\
\text { Thailand }\end{array}$ \\
\hline Japan & 5.0 & 2.8 & 10.7 & 18.7 & 10.5 & 8.2 & 6.8 & 19.5 \\
\hline United States & 0.2 & -0.1 & -0.2 & -0.5 & -0.2 & -0.7 & -0.1 & -1.4 \\
\hline Canada & 0.0 & -0.0 & -0.0 & -0.0 & -0.0 & -0.1 & -0.1 & -0.1 \\
\hline Australia & 0.0 & 0.0 & -0.0 & -0.0 & 0.0 & 0.0 & 0.0 & -0.0 \\
\hline New Zealand & 0.0 & -0.0 & -0.0 & 0.0 & 0.0 & 0.0 & 0.0 & -0.0 \\
\hline EU and EFTA & 0.5 & -0.3 & -0.7 & -0.7 & -0.3 & -0.1 & -0.7 & -2.8 \\
\hline Hong Kong & -0.0 & -0.0 & -0.0 & 0.0 & 0.0 & -0.0 & 0.0 & -0.0 \\
\hline China & 0.1 & 0.0 & -0.1 & 0.0 & 0.1 & -0.0 & -0.1 & 0.1 \\
\hline Korea & 0.0 & -0.0 & -0.2 & 2.2 & -0.2 & -0.0 & -0.1 & -0.1 \\
\hline Singapore & 0.6 & -0.0 & -0.0 & -0.0 & -0.0 & -0.0 & -0.0 & -0.2 \\
\hline Taiwan & 0.0 & -0.0 & -0.1 & -0.1 & -0.1 & -0.0 & -0.0 & -0.2 \\
\hline Indonesia & 0.0 & 0.0 & 1.7 & 0.1 & 0.0 & 0.0 & -0.0 & 0.1 \\
\hline Malaysia & -0.0 & -0.0 & -0.0 & -0.0 & 0.3 & -0.0 & -0.0 & -0.2 \\
\hline Philippines & 0.0 & -0.0 & -0.0 & 0.0 & -0.0 & -0.0 & 0.9 & -0.0 \\
\hline Thailand & 0.0 & -0.0 & -0.0 & -0.0 & -0.0 & -0.0 & -0.0 & -0.5 \\
\hline Rest of Asia & 0.0 & 0.0 & -0.0 & 0.0 & 0.0 & 0.0 & -0.0 & -0.1 \\
\hline Chile & 0.0 & 0.9 & 0.0 & 0.0 & 0.0 & 0.0 & 0.0 & -0.0 \\
\hline Mexico & 0.0 & -0.0 & -0.0 & -0.0 & -0.0 & 3.3 & -0.0 & -0.1 \\
\hline Central America and the Carribean (CAC) & 0.0 & 0.0 & 0.0 & -0.0 & 0.0 & -0.0 & 0.0 & 0.0 \\
\hline South America & 0.0 & 0.1 & -0.0 & 0.1 & 0.0 & -0.0 & -0.0 & -0.2 \\
\hline Morocco & 0.0 & -0.0 & -0.0 & 0.0 & 0.0 & 0.0 & 0.0 & -0.0 \\
\hline Southern African Customs Union (SACU) & 0.0 & 0.0 & -0.0 & -0.1 & -0.0 & 0.0 & -0.0 & -0.0 \\
\hline Total & 6.7 & 3.5 & 11.1 & 19.7 & 10.1 & 10.6 & 6.7 & 13.5 \\
\hline
\end{tabular}




\begin{tabular}{|c|c|c|c|c|c|c|c|c|}
\hline Percent & $\begin{array}{l}\text { Japan- } \\
\text { Singapore }\end{array}$ & $\begin{array}{l}\text { Japan- } \\
\text { Chile }\end{array}$ & $\begin{array}{c}\text { Japan- } \\
\text { Indonesia }\end{array}$ & $\begin{array}{l}\text { Japan- } \\
\text { Korea }\end{array}$ & $\begin{array}{c}\text { Japan- } \\
\text { Malaysia }\end{array}$ & $\begin{array}{l}\text { Japan- } \\
\text { Mexico }\end{array}$ & $\begin{array}{c}\text { Japan- } \\
\text { Philippines }\end{array}$ & $\begin{array}{l}\text { Japan- } \\
\text { Thailand }\end{array}$ \\
\hline Japan & 0.1 & 0.1 & 0.2 & 0.4 & 0.2 & 0.2 & 0.1 & 0.4 \\
\hline United States & 0.0 & 0.0 & 0.0 & -0.0 & 0.0 & -0.0 & -0.0 & -0.0 \\
\hline Canada & 0.0 & 0.0 & 0.0 & 0.0 & 0.0 & -0.0 & -0.0 & -0.0 \\
\hline Australia & 0.0 & 0.0 & 0.0 & 0.0 & 0.0 & 0.0 & 0.0 & -0.0 \\
\hline New Zealand & 0.0 & 0.0 & 0.0 & 0.0 & 0.0 & 0.0 & 0.0 & -0.0 \\
\hline EU and EFTA & 0.0 & 0.0 & -0.0 & -0.0 & 0.0 & 0.0 & -0.0 & -0.0 \\
\hline Hong Kong & -0.0 & 0.0 & 0.0 & 0.0 & 0.0 & 0.0 & 0.0 & -0.0 \\
\hline China & 0.0 & 0.0 & 0.0 & 0.0 & 0.0 & 0.0 & -0.0 & 0.0 \\
\hline Korea & 0.0 & -0.0 & -0.0 & 0.4 & -0.0 & 0.0 & -0.0 & -0.0 \\
\hline Singapore & 0.7 & 0.0 & -0.0 & -0.0 & -0.0 & -0.0 & 0.0 & -0.2 \\
\hline Taiwan & 0.0 & 0.0 & -0.0 & -0.0 & -0.0 & -0.0 & -0.0 & -0.1 \\
\hline Indonesia & 0.0 & 0.0 & 0.7 & 0.0 & 0.0 & 0.0 & -0.0 & 0.1 \\
\hline Malaysia & -0.0 & 0.0 & -0.0 & -0.0 & 0.2 & -0.0 & -0.0 & -0.2 \\
\hline Philippines & 0.0 & 0.0 & -0.0 & 0.0 & 0.0 & -0.0 & 0.9 & -0.0 \\
\hline Thailand & 0.0 & 0.0 & -0.0 & -0.0 & -0.0 & 0.0 & -0.0 & -0.3 \\
\hline Rest of Asia & 0.0 & 0.0 & 0.0 & 0.0 & 0.0 & 0.0 & -0.0 & -0.0 \\
\hline Chile & 0.0 & 1.0 & 0.0 & 0.0 & 0.0 & 0.0 & 0.0 & -0.0 \\
\hline Mexico & 0.0 & 0.0 & 0.0 & 0.0 & 0.0 & 0.7 & -0.0 & -0.0 \\
\hline Central America and the Carribean (CAC) & 0.0 & 0.0 & 0.0 & 0.0 & 0.0 & 0.0 & 0.0 & 0.0 \\
\hline South America & 0.0 & 0.0 & 0.0 & 0.0 & 0.0 & 0.0 & -0.0 & -0.0 \\
\hline Morocco & 0.0 & 0.0 & 0.0 & 0.0 & 0.0 & 0.0 & 0.0 & -0.0 \\
\hline Southern African Customs Union (SACU) & 0.0 & 0.0 & 0.0 & -0.0 & 0.0 & 0.0 & -0.0 & -0.0 \\
\hline
\end{tabular}


Table 13. Sectoral Employment Effects for Japan of Bilateral Negotiating Options

(Number of Workers and Percent of

Employment)

\begin{tabular}{|c|c|c|c|c|c|c|c|c|}
\hline Number of Workers & $\begin{array}{c}\text { Japan- } \\
\text { Singapore }\end{array}$ & $\begin{array}{c}\text { Japan- } \\
\text { Chile }\end{array}$ & $\begin{array}{c}\text { Japan- } \\
\text { Indonesia }\end{array}$ & $\begin{array}{l}\text { Japan- } \\
\text { Korea }\end{array}$ & $\begin{array}{c}\text { Japan- } \\
\text { Malaysia }\end{array}$ & $\begin{array}{l}\text { Japan- } \\
\text { Mexico }\end{array}$ & $\begin{array}{c}\text { Japan- } \\
\text { Philippines }\end{array}$ & $\begin{array}{c}\text { Japan- } \\
\text { Thailand }\end{array}$ \\
\hline Agriculture & $(617)$ & $(4,478)$ & $(8,578)$ & $(9,008)$ & $(3,577)$ & $(3,000)$ & $(5,462)$ & $(19,994)$ \\
\hline Mining & 60 & 188 & 196 & $(364)$ & $(228)$ & (83) & $(106)$ & (202) \\
\hline Food, Beverages \& Tobacco & $(688)$ & $(4,080)$ & $(6,176)$ & $(5,893)$ & $(1,757)$ & $(1,061)$ & $(1,437)$ & $(18,178)$ \\
\hline Textiles & 182 & 176 & (29) & $(3,080)$ & (634) & $(338)$ & 311 & 1,095 \\
\hline Wearing Apparel & (2) & 30 & $(432)$ & $(1,423)$ & (391) & (86) & $(320)$ & (518) \\
\hline Leather products \& Footwear & (22) & 33 & $(732)$ & $(1,317)$ & $(145)$ & (65) & (73) & (183) \\
\hline Wood \& Wood Products & 73 & 117 & $(4,489)$ & $(825)$ & $(2,684)$ & $(116)$ & $(155)$ & (296) \\
\hline Chemicals & 38 & 373 & 1,186 & 1,132 & 169 & (1) & 237 & 3,122 \\
\hline Non-metallic Min. Products & 91 & 95 & 246 & 1,016 & 253 & 83 & 207 & 987 \\
\hline Metal Products & 460 & 798 & 2,670 & 2,576 & 1,899 & 512 & 790 & 4,988 \\
\hline Transportation Equipment & 500 & 1,214 & 8,079 & $(3,104)$ & 9,102 & 926 & 2,165 & 12,379 \\
\hline Machinery \& Equipment & 2,390 & 3,049 & 2,723 & 14,480 & $(3,583)$ & 2,675 & 862 & 6,011 \\
\hline Other Manufactures & 22 & 42 & 7 & $(178)$ & (55) & 7 & (67) & 63 \\
\hline Elec., Gas \& Water & 13 & 31 & 91 & 88 & 59 & 41 & 39 & 184 \\
\hline Construction & (51) & 109 & 526 & 490 & 429 & 302 & 787 & 1,207 \\
\hline Trade \& Transport & $(2,260)$ & 862 & (515) & 876 & $(2,189)$ & $(2,329)$ & (51) & (396) \\
\hline Other Private Services & $(146)$ & 409 & 1,485 & 1,376 & 602 & 1,052 & 621 & 2,375 \\
\hline Government Services & (44) & 1,031 & 3,741 & 3,159 & 2,728 & 1,482 & 1,651 & 7,357 \\
\hline
\end{tabular}




\begin{tabular}{|c|c|c|c|c|c|c|c|c|}
\hline Percent & $\begin{array}{c}\text { Japan- } \\
\text { Singapore }\end{array}$ & $\begin{array}{l}\text { Japan- } \\
\text { Chile }\end{array}$ & $\begin{array}{c}\text { Japan- } \\
\text { Indonesia }\end{array}$ & $\begin{array}{l}\text { Japan- } \\
\text { Korea }\end{array}$ & $\begin{array}{c}\text { Japan- } \\
\text { Malaysia }\end{array}$ & $\begin{array}{c}\text { Japan- } \\
\text { Mexico }\end{array}$ & $\begin{array}{c}\text { Japan- } \\
\text { Philippines }\end{array}$ & $\begin{array}{c}\text { Japan- } \\
\text { Thailand }\end{array}$ \\
\hline Agriculture & -0.0 & -0.1 & -0.3 & -0.3 & -0.1 & -0.1 & -0.2 & -0.6 \\
\hline Mining & 0.1 & 0.3 & 0.3 & -0.5 & -0.3 & -0.1 & -0.2 & -0.3 \\
\hline Food, Beverages \& Tobacco & -0.0 & -0.2 & -0.4 & -0.3 & -0.1 & -0.1 & -0.1 & -1.0 \\
\hline Textiles & 0.0 & 0.0 & 0.0 & -0.5 & -0.1 & -0.1 & 0.1 & 0.2 \\
\hline Wearing Apparel & 0.0 & 0.0 & -0.1 & -0.3 & -0.1 & -0.0 & -0.1 & -0.1 \\
\hline Leather products \& Footwear & -0.0 & 0.0 & -0.8 & -1.4 & -0.2 & -0.1 & -0.1 & -0.2 \\
\hline Wood \& Wood Products & 0.0 & 0.0 & -0.3 & -0.1 & -0.2 & -0.0 & -0.0 & -0.0 \\
\hline Chemicals & 0.0 & 0.0 & 0.1 & 0.1 & 0.0 & 0.0 & 0.0 & 0.2 \\
\hline Non-metallic Min. Products & 0.0 & 0.0 & 0.0 & 0.2 & 0.0 & 0.0 & 0.0 & 0.2 \\
\hline Metal Products & 0.0 & 0.0 & 0.2 & 0.2 & 0.1 & 0.0 & 0.0 & 0.3 \\
\hline Transportation Equipment & 0.0 & 0.1 & 0.6 & -0.2 & 0.7 & 0.1 & 0.2 & 0.9 \\
\hline Machinery \& Equipment & 0.1 & 0.1 & 0.1 & 0.3 & -0.1 & 0.1 & 0.0 & 0.1 \\
\hline Other Manufactures & 0.0 & 0.0 & 0.0 & -0.1 & -0.0 & 0.0 & -0.0 & 0.0 \\
\hline Elec., Gas \& Water & 0.0 & 0.0 & 0.0 & 0.0 & 0.0 & 0.0 & 0.0 & 0.1 \\
\hline Construction & 0.0 & 0.0 & 0.0 & 0.0 & 0.0 & 0.0 & 0.0 & 0.0 \\
\hline Trade \& Transport & -0.0 & 0.0 & 0.0 & 0.0 & -0.0 & -0.0 & 0.0 & 0.0 \\
\hline Other Private Services & 0.0 & 0.0 & 0.0 & 0.0 & 0.0 & 0.0 & 0.0 & 0.0 \\
\hline Government Services & 0.0 & 0.0 & 0.0 & 0.0 & 0.0 & 0.0 & 0.0 & 0.1 \\
\hline
\end{tabular}


Table 14. Sectoral Employment Effects for Japan FTA Partner Countries

(Number of Workers and Percent of

Employment)

\begin{tabular}{|c|c|c|c|c|c|c|c|c|}
\hline Number of Workers & $\begin{array}{c}\text { Japan- } \\
\text { Singapore }\end{array}$ & $\begin{array}{c}\text { Japan- } \\
\text { Chile }\end{array}$ & $\begin{array}{c}\text { Japan- } \\
\text { Indonesia }\end{array}$ & $\begin{array}{l}\text { Japan- } \\
\text { Korea }\end{array}$ & $\begin{array}{c}\text { Japan- } \\
\text { Malaysia }\end{array}$ & $\begin{array}{l}\text { Japan- } \\
\text { Mexico }\end{array}$ & $\begin{array}{c}\text { Japan- } \\
\text { Philippines }\end{array}$ & $\begin{array}{l}\text { Japan- } \\
\text { Thailand }\end{array}$ \\
\hline Agriculture & 86 & 23,872 & 373,610 & 46,095 & 14,439 & 17,091 & 111,720 & $1,034,564$ \\
\hline Mining & (5) & $(3,378)$ & $(14,970)$ & (44) & (517) & $(202)$ & $(1,919)$ & $(4,884)$ \\
\hline Food, Beverages \& Tobacco & 1,385 & 15,807 & 38,452 & 8,504 & 3,585 & 2,139 & 1,189 & 89,872 \\
\hline Textiles & (10) & $(768)$ & $(6,202)$ & 10,558 & 390 & $(875)$ & 1,947 & $(56,736)$ \\
\hline Wearing Apparel & 106 & $(376)$ & 10,027 & 5,818 & 2,913 & $(279)$ & 14,455 & $(80,148)$ \\
\hline Leather products \& Footwear & 51 & (317) & 28,661 & 5,820 & (23) & $(123)$ & 2,169 & $(5,587)$ \\
\hline Wood \& Wood Products & $(145)$ & $(1,970)$ & 39,158 & $(868)$ & 11,665 & $(850)$ & $(2,565)$ & $(20,450)$ \\
\hline Chemicals & (205) & $(2,464)$ & $(30,953)$ & $(2,269)$ & $(4,552)$ & $(2,629)$ & $(5,869)$ & $(31,731)$ \\
\hline Non-metallic Min. Products & (48) & (613) & $(10,341)$ & $(2,474)$ & $(1,521)$ & $(800)$ & $(3,681)$ & $(18,953)$ \\
\hline Metal Products & $(430)$ & $(4,750)$ & $(29,701)$ & $(4,036)$ & $(4,579)$ & $(1,282)$ & $(4,299)$ & $(57,330)$ \\
\hline Transportation Equipment & $(195)$ & $(1,544)$ & $(32,180)$ & $(1,251)$ & $(11,180)$ & $(2,074)$ & $(5,728)$ & $(23,004)$ \\
\hline Machinery \& Equipment & $(2,809)$ & $(2,894)$ & $(18,322)$ & $(17,068)$ & 1,832 & 1,165 & 6,758 & $(19,945)$ \\
\hline Other Manufactures & (18) & $(114)$ & $(2,901)$ & $(237)$ & (333) & $(254)$ & (70) & $(9,951)$ \\
\hline Elec., Gas \& Water & (19) & $(384)$ & $(1,798)$ & $(100)$ & $(177)$ & $(101)$ & $(997)$ & $(9,851)$ \\
\hline Construction & $(106)$ & $(2,293)$ & $(30,482)$ & $(5,234)$ & $(3,628)$ & $(1,506)$ & $(26,648)$ & $(120,418)$ \\
\hline Trade \& Transport & 2,332 & $(10,634)$ & $(195,924)$ & $(28,848)$ & 6,096 & 6,602 & $(38,495)$ & $(430,875)$ \\
\hline Other Private Services & $(244)$ & $(2,028)$ & $(7,742)$ & $(4,533)$ & $(3,499)$ & $(4,274)$ & $(11,163)$ & $(57,822)$ \\
\hline Government Services & 273 & $(5,153)$ & $(108,394)$ & $(9,834)$ & $(10,912)$ & $(11,749)$ & $(36,804)$ & $(176,753)$ \\
\hline
\end{tabular}




\begin{tabular}{|c|c|c|c|c|c|c|c|c|}
\hline Percent & $\begin{array}{c}\text { Japan- } \\
\text { Singapore }\end{array}$ & $\begin{array}{l}\text { Japan- } \\
\text { Chile }\end{array}$ & $\begin{array}{c}\text { Japan- } \\
\text { Indonesia }\end{array}$ & $\begin{array}{l}\text { Japan- } \\
\text { Korea }\end{array}$ & $\begin{array}{c}\text { Japan- } \\
\text { Malaysia }\end{array}$ & $\begin{array}{c}\text { Japan- } \\
\text { Mexico }\end{array}$ & $\begin{array}{c}\text { Japan- } \\
\text { Philippines }\end{array}$ & $\begin{array}{l}\text { Japan- } \\
\text { Thailand }\end{array}$ \\
\hline Agriculture & 1.6 & 3.0 & 1.0 & 2.0 & 1.0 & 0.2 & 1.0 & 6.0 \\
\hline Mining & -0.8 & -4.0 & -1.7 & -0.2 & -1.4 & -0.2 & -1.6 & -11.0 \\
\hline Food, Beverages \& Tobacco & 7.4 & 5.4 & 1.8 & 2.7 & 2.1 & 0.1 & 0.2 & 13.3 \\
\hline Textiles & -0.5 & -1.7 & -0.4 & 2.5 & 0.6 & -0.2 & 1.0 & -8.4 \\
\hline Wearing Apparel & 1.1 & -1.0 & 1.0 & 2.2 & 3.1 & -0.2 & 3.0 & -6.7 \\
\hline Leather products \& Footwear & 3.9 & -1.2 & 2.7 & 6.0 & -0.3 & -0.1 & 3.3 & -7.1 \\
\hline Wood \& Wood Products & -0.4 & -1.5 & 2.0 & -0.2 & 3.2 & -0.2 & -0.9 & -9.2 \\
\hline Chemicals & -0.4 & -2.1 & -2.5 & -0.5 & -1.9 & -0.3 & -2.1 & -12.0 \\
\hline Non-metallic Min. Products & -0.6 & -1.8 & -2.1 & -1.3 & -1.7 & -0.3 & -3.4 & -9.5 \\
\hline Metal Products & -1.0 & -4.6 & -5.4 & -0.8 & -3.0 & -0.3 & -2.5 & -17.0 \\
\hline Transportation Equipment & -0.5 & -6.0 & -9.5 & -0.2 & -14.3 & -0.4 & -7.8 & -17.9 \\
\hline Machinery \& Equipment & -1.4 & -6.8 & -3.1 & -1.3 & 0.3 & 0.2 & 1.6 & -7.0 \\
\hline Other Manufactures & -0.4 & -3.2 & -1.5 & -0.3 & -1.1 & -0.4 & -0.1 & -8.7 \\
\hline Elec., Gas \& Water & -0.2 & -1.3 & -0.8 & -0.1 & -0.4 & -0.1 & -0.7 & -5.7 \\
\hline Construction & -0.1 & -0.5 & -0.7 & -0.3 & -0.5 & -0.1 & -1.6 & -6.2 \\
\hline Trade \& Transport & 0.4 & -0.8 & -0.9 & -0.4 & 0.3 & 0.1 & -0.7 & -8.1 \\
\hline Other Private Services & -0.1 & -0.5 & -1.2 & -0.2 & -0.8 & -0.3 & -1.7 & -6.8 \\
\hline Government Services & 0.1 & -0.4 & -0.9 & -0.3 & -0.6 & -0.1 & -0.7 & -5.2 \\
\hline
\end{tabular}


Table 15. Welfare Effects of Bilateral FTAs and Unilateral and Global Free Trade

\begin{tabular}{|c|c|c|c|c|c|c|c|c|c|c|c|c|c|c|c|c|c|c|}
\hline \multirow{2}{*}{\multicolumn{2}{|c|}{ Bilateral FTAs }} & \multicolumn{8}{|c|}{ United States } & \multicolumn{8}{|c|}{ Japan } & \multirow{3}{*}{\begin{tabular}{|l}
$\begin{array}{l}\text { No. of } \\
\text { Positive } \\
\text { Effects }\end{array}$ \\
11 \\
\end{tabular}} \\
\hline & & \multirow{2}{*}{\begin{tabular}{|c}
1 \\
US- \\
CHL
\end{tabular}} & \multirow{2}{*}{$\begin{array}{c}2 \\
\text { US- } \\
\text { SGP }\end{array}$} & \multirow{2}{*}{$\begin{array}{c}3 \\
\text { US- } \\
\text { CAC }\end{array}$} & \multirow{2}{*}{\begin{tabular}{|l|}
\multicolumn{1}{|c|}{4} \\
US- \\
AUS
\end{tabular}} & \multirow{2}{*}{\begin{tabular}{|l|}
\multicolumn{1}{|c|}{5} \\
US- \\
MOR
\end{tabular}} & \multirow{2}{*}{\begin{tabular}{l}
\multicolumn{1}{c}{6} \\
US- \\
SACU
\end{tabular}} & \multirow{2}{*}{ 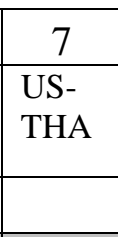 } & \multirow{2}{*}{$\begin{array}{c}8 \\
\text { FTAA }\end{array}$} & $\begin{array}{c}9 \\
\text { JPN- } \\
\text { SGP }\end{array}$ & $\begin{array}{c}10 \\
\text { JPN- } \\
\text { CHL }\end{array}$ & $\begin{array}{c}11 \\
\text { JPN- } \\
\text { IDN }\end{array}$ & $\begin{array}{c}12 \\
\text { JPN- } \\
\text { KOR }\end{array}$ & $\begin{array}{r}13 \\
\text { JPN- } \\
\text { MYS }\end{array}$ & \begin{tabular}{|c|}
14 \\
JPN- \\
MEX
\end{tabular} & $\begin{array}{c}15 \\
\text { JPN- } \\
\text { PHL }\end{array}$ & \begin{tabular}{|c|}
16 \\
JPN- \\
THA
\end{tabular} & \\
\hline 1 & Japan & & & & & & & & & $\mathrm{X}$ & $\mathbf{X}$ & $\mathbf{X}$ & $\mathbf{X}$ & $\mathbf{X}$ & $\mathbf{X}$ & $\mathbf{X}$ & $\mathbf{X}$ & \\
\hline 2 & US & $\mathbf{X}$ & $\mathbf{X}$ & $\mathbf{X}$ & $\mathbf{X}$ & $\mathbf{X}$ & $\mathbf{X}$ & $\mathbf{X}$ & $\mathbf{X}$ & & & & & & & & & 10 \\
\hline 3 & Canada & & & & & & & & $\mathbf{X}$ & & & & & & & & & 8 \\
\hline 4 & Australia & & & & $\mathbf{X}$ & & & & & & & & & & & & & 9 \\
\hline 5 & New Zealand & & & & & & & & & & & & & & & & & 9 \\
\hline 6 & EU and EFTA & & & & & & & & & & & & & & & & & 4 \\
\hline 7 & Hong Kong & & & & & & & & & & & & & & & & & 7 \\
\hline 8 & China & & & & & & & & & & & & & & & & & 8 \\
\hline 9 & Korea & & & & & & & & & & & & $\mathrm{X}$ & & & & & 5 \\
\hline 10 & Singapore & & $\mathbf{X}$ & & & & & & & $\mathbf{X}$ & & & & & & & & 7 \\
\hline 11 & Taiwan & & & & & & & & & & & & & & & & & 5 \\
\hline 12 & Indonesia & & & & & & & & & & & $\mathbf{X}$ & & & & & & 12 \\
\hline 13 & Malaysia & & & & & & & & & & & & & $\mathrm{X}$ & & & & 6 \\
\hline 14 & Philippines & & & & & & & & & & & & & & & $\mathrm{X}$ & & 7 \\
\hline 15 & Thailand & & & & & & & $\mathrm{X}$ & & & & & & & & & $\mathbf{X}$ & 6 \\
\hline 16 & Rest of Asia & & & & & & & & & & & & & & & & & 9 \\
\hline 17 & Chile & $\mathbf{X}$ & & & & & & & $\mathbf{X}$ & & $\mathbf{X}$ & & & & & & & 13 \\
\hline 18 & Mexico & & & & & & & & $\mathrm{X}$ & & & & & & $\mathbf{X}$ & & & 6 \\
\hline 19 & CAC & & & $\mathbf{X}$ & & & & & $\mathbf{X}$ & & & & & & & & & 11 \\
\hline 20 & South America & & & & & & & & $\mathbf{X}$ & & & & & & & & & 10 \\
\hline 21 & Morocco & & & & & $X$ & & & & & & & & & & & & 8 \\
\hline 22 & SACU & & & & & & $\mathbf{X}$ & & & & & & & & & & & 8 \\
\hline $\begin{array}{l}\text { No. } \\
\text { Effe }\end{array}$ & $\begin{array}{l}\text { of Positive } \\
\text { ects }\end{array}$ & 14 & 20 & 2 & 6 & 22 & 11 & 6 & 8 & 20 & 9 & 4 & 11 & 12 & 9 & 21 & 4 & \\
\hline
\end{tabular}


Unilateral and Global

Free Trade

Unilateral Free Trade

\begin{tabular}{|c|c|c|c|c|c|c|c|c|c|c|c|c|c|c|c|c|c|}
\hline & \multirow{3}{*}{\begin{tabular}{|r|} 
US \\
1
\end{tabular}} & \multirow{3}{*}{\begin{tabular}{|c|} 
JPN \\
2 \\
\end{tabular}} & \multirow{3}{*}{\begin{tabular}{|c|} 
AUS \\
3 \\
\end{tabular}} & \multirow{3}{*}{\begin{tabular}{|c|} 
KOR \\
4 \\
\end{tabular}} & \multirow{3}{*}{$\begin{array}{c}\text { SGP } \\
5\end{array}$} & \multirow{3}{*}{\begin{tabular}{|c|} 
IDN \\
6
\end{tabular}} & \multirow{3}{*}{\begin{tabular}{|c|} 
MYS \\
7 \\
\end{tabular}} & \multirow{3}{*}{\begin{tabular}{|c|} 
PHL \\
8 \\
\end{tabular}} & \multirow{3}{*}{\begin{tabular}{|c|} 
THA \\
9 \\
\end{tabular}} & \multirow{3}{*}{\begin{tabular}{|l|}
$\mathrm{CH}$ \\
$\mathrm{L}$ \\
10
\end{tabular}} & \multirow{3}{*}{$\begin{array}{c}\text { CAC } \\
11\end{array}$} & \multirow{3}{*}{\begin{tabular}{c|} 
MEX \\
12 \\
\end{tabular}} & \multirow{3}{*}{\begin{tabular}{c|} 
MOR \\
13 \\
\end{tabular}} & \multirow{3}{*}{\begin{tabular}{|c|} 
SACU \\
14 \\
\end{tabular}} & \multirow{3}{*}{$\begin{array}{l}\text { FT } \\
15\end{array}$} & \multirow{3}{*}{$\begin{array}{l}\text { No. of } \\
\text { positive } \\
\text { effects }\end{array}$} \\
\hline & & & & & & & & & & & & & & & & & \\
\hline & & & & & & & & & & & & & & & & & \\
\hline 1 & Japan & & $\mathbf{X}$ & & & & & & & & & & & & & $\mathbf{X}$ & 15 \\
\hline 2 & US & $\mathbf{X}$ & & & & & & & & & & & & & & $\mathbf{X}$ & 14 \\
\hline 3 & Canada & & & & & & & & & & & & & & & $\mathbf{X}$ & 13 \\
\hline 4 & Australia & & & $\mathbf{X}$ & & & & & & & & & & & & $\mathbf{X}$ & 15 \\
\hline 5 & New Zealand & & & & & & & & & & & & & & & $\mathbf{X}$ & 14 \\
\hline 6 & $\begin{array}{l}\text { EU and } \\
\text { EFTA }\end{array}$ & & & & & & & & & & & & & & & $\mathbf{X}$ & 15 \\
\hline 7 & Hong Kong & & & & & & & & & & & & & & & $\mathbf{X}$ & 14 \\
\hline 8 & China & & & & & & & & & & & & & & & $\mathbf{X}$ & 13 \\
\hline 9 & Korea & & & & $\mathbf{X}$ & & & & & & & & & & & $\mathbf{X}$ & 15 \\
\hline 10 & Singapore & & & & & $\mathrm{X}$ & & & & & & & & & & $\mathbf{X}$ & 15 \\
\hline 11 & Taiwan & & & & & & & & & & & & & & & $\mathbf{X}$ & 15 \\
\hline 12 & Indonesia & & & & & & $\mathrm{X}$ & & & & & & & & & $\mathbf{X}$ & 15 \\
\hline 13 & Malaysia & & & & & & & $\mathrm{X}$ & & & & & & & & $\mathbf{X}$ & 15 \\
\hline 14 & Philippines & & & & & & & & $\mathbf{X}$ & & & & & & & $\mathbf{X}$ & 15 \\
\hline 15 & Thailand & & & & & & & & & $\mathbf{X}$ & & & & & & $\mathbf{X}$ & 14 \\
\hline 16 & Rest of Asia & & & & & & & & & & & & & & & $\mathbf{X}$ & 15 \\
\hline 17 & Chile & & & & & & & & & & $\mathbf{X}$ & & & & & $\mathbf{X}$ & 15 \\
\hline 18 & Mexico & & & & & & & & & & & & $\mathbf{X}$ & & & $\mathbf{X}$ & 14 \\
\hline 19 & CAC & & & & & & & & & & & $\mathbf{X}$ & & & & $\mathbf{X}$ & 15 \\
\hline 20 & $\begin{array}{l}\text { South } \\
\text { America }\end{array}$ & & & & & & & & & & & & & & & $\mathbf{X}$ & 15 \\
\hline 21 & Morocco & & & & & & & & & & & & & $\mathrm{X}$ & & $X$ & 15 \\
\hline 22 & SACU & & & & & & & & & & & & & & $\mathbf{X}$ & $\mathbf{X}$ & 14 \\
\hline of & & 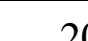 & 19 & 21 & 21 & 27 & 27 & 27 & 27 & 27 & 27 & 27 & ח & & & 22 & \\
\hline
\end{tabular}

Notes: 1) Shaded cells indicate countries with positive welfare effects while white cells indicate countries with negative welfare effects.

2) "X" indicates unilateral free trade

countries.

Table 16. Welfare Effects of Unilateral and Global Free Trade 
(Billions of Dollars and Percent of GNP)

\begin{tabular}{|c|c|c|c|c|c|c|c|c|c|c|c|c|c|c|c|}
\hline \multirow[b]{2}{*}{ \$ (Billions) } & \multicolumn{14}{|c|}{ " Unilateral Free Trade } & \multirow{2}{*}{$\begin{array}{c}\text { Global } \\
\text { Free Trade }\end{array}$} \\
\hline & United States & Japan & Australia & Korea & Singapore & Indonesia & Malaysia & Philippines & Thailand & Chile & Mexico & CAC & Morocco & SACU & \\
\hline Japan & 21.9 & 200.3 & 4.1 & 7.6 & 0.6 & 8.1 & 5.8 & 5.3 & 11.8 & 1.6 & 2.7 & 4.6 & 1.1 & 2.5 & 401.8 \\
\hline United States & 320.2 & 10.6 & 2.3 & 11.8 & 1.6 & 7.1 & 2.6 & 9.7 & 8.0 & 2.0 & -5.2 & 9.1 & 1.9 & 3.2 & 542.5 \\
\hline Canada & -9.7 & 0.9 & 0.3 & 1.7 & 0.2 & 0.9 & 0.3 & 1.4 & 1.0 & 0.2 & -0.6 & 0.8 & 0.2 & 0.3 & 50.1 \\
\hline Australia & 5.4 & 3.0 & 4.6 & 1.0 & 0.2 & 0.4 & 0.5 & 0.6 & 0.9 & 0.0 & 0.4 & 0.3 & 0.1 & 0.2 & 30.1 \\
\hline New Zealand & 1.3 & 1.4 & -0.2 & 0.3 & 0.1 & 0.1 & 0.1 & 0.1 & 0.2 & 0.0 & 0.2 & 0.1 & 0.1 & 0.1 & 11.5 \\
\hline EU and EFTA & 128.9 & 33.4 & 4.0 & 20.8 & 3.4 & 13.6 & 6.7 & 15.1 & 14.9 & 3.1 & 12.2 & 8.3 & 5.3 & 8.5 & 796.2 \\
\hline Hong Kong & 5.2 & 0.9 & 0.1 & 0.8 & 0.1 & 0.2 & 0.3 & 0.4 & 0.7 & 0.1 & 0.0 & 0.1 & -0.0 & 0.2 & 18.1 \\
\hline China & 5.3 & -4.3 & 1.1 & -1.0 & 0.1 & 0.7 & 0.4 & 0.5 & 1.5 & 0.2 & 0.3 & 0.3 & 0.1 & 0.4 & 105.0 \\
\hline Korea & 5.0 & 0.5 & 0.8 & 34.9 & 0.1 & 2.3 & 0.4 & 1.1 & 1.1 & 0.3 & 0.6 & 0.5 & 0.1 & 0.8 & 73.2 \\
\hline Singapore & 2.1 & 0.8 & 0.1 & 0.9 & 1.1 & 0.6 & 1.7 & 0.8 & 1.5 & 0.1 & 0.2 & 0.2 & 0.0 & 0.1 & 19.9 \\
\hline Taiwan & 4.9 & 1.5 & 0.6 & 0.7 & 0.1 & 0.8 & 0.7 & 0.9 & 1.1 & 0.2 & 0.3 & 0.1 & 0.1 & 0.3 & 60.7 \\
\hline Indonesia & 2.2 & 1.5 & 0.2 & 1.0 & 0.1 & 11.9 & 0.4 & 0.5 & 0.7 & 0.1 & 0.1 & 0.1 & 0.0 & 0.1 & 25.8 \\
\hline Malaysia & 1.1 & 0.6 & 0.1 & 1.1 & 0.4 & 0.5 & 4.0 & 0.6 & 1.0 & 0.1 & 0.1 & 0.1 & 0.0 & 0.2 & 18.2 \\
\hline Philippines & 1.6 & 0.6 & 0.1 & 0.7 & 0.1 & 0.4 & 0.2 & 7.5 & 0.4 & 0.1 & 0.0 & 0.0 & 0.0 & 0.1 & 17.0 \\
\hline Thailand & 2.3 & -0.6 & 0.2 & 0.6 & 0.2 & 0.4 & 0.2 & 0.3 & 14.7 & 0.1 & 0.2 & 0.2 & 0.0 & 0.1 & 27.4 \\
\hline Rest of Asia & 3.7 & 1.2 & 0.4 & 1.1 & 0.1 & 0.5 & 0.5 & 0.4 & 0.5 & 0.1 & 0.3 & 0.3 & 0.0 & 0.3 & 40.8 \\
\hline Chile & 0.8 & 0.5 & 0.0 & 0.3 & 0.0 & 0.0 & 0.1 & 0.1 & 0.1 & 5.2 & 0.3 & 0.1 & 0.0 & 0.0 & 10.8 \\
\hline Mexico & -5.6 & 1.1 & 0.1 & 0.7 & 0.1 & 0.3 & 0.0 & 0.2 & 0.2 & 0.3 & 26.4 & 0.4 & 0.1 & 0.3 & 33.6 \\
\hline $\begin{array}{l}\text { Central America } \\
\text { and the Carribean } \\
\text { (CAC) }\end{array}$ & 4.0 & 1.3 & 0.0 & 0.5 & 0.0 & 0.2 & 0.1 & 0.1 & 0.2 & 0.1 & 0.2 & 6.2 & 0.0 & 0.1 & 17.7 \\
\hline South America & 4.7 & 2.8 & 0.3 & 2.3 & 0.3 & 0.9 & 0.5 & 0.9 & 1.2 & 1.4 & 1.2 & 1.7 & 0.4 & 1.0 & 96.5 \\
\hline Morocco & 0.5 & 0.4 & 0.0 & 0.1 & 0.0 & 0.0 & 0.0 & 0.0 & 0.0 & 0.0 & 0.0 & 0.0 & 1.6 & 0.0 & 4.8 \\
\hline $\begin{array}{l}\text { Southern African } \\
\text { Customs Union } \\
\text { (SACU) }\end{array}$ & 1.1 & -0.2 & 0.1 & 0.2 & 0.0 & 0.0 & 0.0 & 0.1 & 0.2 & 0.0 & 0.2 & 0.1 & 0.0 & 13.6 & 15.5 \\
\hline Total & 507.0 & 258.0 & 19.3 & 88.0 & 9.0 & 50.0 & 25.6 & 46.8 & 61.9 & 15.2 & 40.0 & 33.7 & 11.3 & 32.3 & $2,417.3$ \\
\hline
\end{tabular}


Unilateral Free Trade

\begin{tabular}{|c|c|c|c|c|c|c|c|c|c|c|c|c|c|c|c|}
\hline Percent & United States & Japan & Australia & Korea & Singapore & Indonesia & Malaysia & Philippines & Thailand & Chile & Mexico & $\mathrm{CAC}$ & Morocco & SACU & Free Trade \\
\hline Japan & 0.4 & 3.7 & 0.1 & 0.1 & 0.0 & 0.1 & 0.1 & 0.1 & 0.2 & 0.0 & 0.0 & 0.1 & 0.0 & 0.0 & 7.4 \\
\hline United States & 3.2 & 0.1 & 0.0 & 0.1 & 0.0 & 0.1 & 0.0 & 0.1 & 0.1 & 0.0 & -0.1 & 0.1 & 0.0 & 0.0 & 5.4 \\
\hline Canada & -1.2 & 0.1 & 0.0 & 0.2 & 0.0 & 0.1 & 0.0 & 0.2 & 0.1 & 0.0 & -0.1 & 0.1 & 0.0 & 0.0 & 6.2 \\
\hline Australia & 1.1 & 0.6 & 0.9 & 0.2 & 0.0 & 0.1 & 0.1 & 0.1 & 0.2 & 0.0 & 0.1 & 0.1 & 0.0 & 0.0 & 6.0 \\
\hline New Zealand & 1.6 & 1.7 & -0.3 & 0.3 & 0.1 & 0.1 & 0.1 & 0.2 & 0.2 & 0.0 & 0.2 & 0.2 & 0.1 & 0.1 & 14.0 \\
\hline EU and EFTA & 1.2 & 0.3 & 0.0 & 0.2 & 0.0 & 0.1 & 0.1 & 0.1 & 0.1 & 0.0 & 0.1 & 0.1 & 0.0 & 0.1 & 7.3 \\
\hline Hong Kong & 2.9 & 0.5 & 0.0 & 0.5 & 0.1 & 0.1 & 0.2 & 0.3 & 0.4 & 0.0 & 0.0 & 0.1 & 0.0 & 0.1 & 10.2 \\
\hline China & 0.5 & -0.4 & 0.1 & -0.1 & 0.0 & 0.1 & 0.0 & 0.0 & 0.1 & 0.0 & 0.0 & 0.0 & 0.0 & 0.0 & 9.6 \\
\hline Korea & 0.9 & 0.1 & 0.1 & 6.3 & 0.0 & 0.4 & 0.1 & 0.2 & 0.2 & 0.1 & 0.1 & 0.1 & 0.0 & 0.1 & 13.2 \\
\hline Singapore & 2.3 & 0.9 & 0.1 & 0.9 & 1.2 & 0.6 & 1.8 & 0.8 & 1.6 & 0.1 & 0.2 & 0.2 & 0.0 & 0.1 & 21.0 \\
\hline Taiwan & 1.3 & 0.4 & 0.1 & 0.2 & 0.0 & 0.2 & 0.2 & 0.2 & 0.3 & 0.1 & 0.1 & 0.0 & 0.0 & 0.1 & 15.9 \\
\hline Indonesia & 0.8 & 0.6 & 0.1 & 0.4 & 0.0 & 4.5 & 0.2 & 0.2 & 0.3 & 0.0 & 0.1 & 0.0 & 0.0 & 0.0 & 9.7 \\
\hline Malaysia & 0.8 & 0.4 & 0.1 & 0.8 & 0.3 & 0.4 & 3.0 & 0.4 & 0.7 & 0.0 & 0.1 & 0.1 & 0.0 & 0.1 & 13.7 \\
\hline Philippines & 1.7 & 0.6 & 0.1 & 0.7 & 0.1 & 0.4 & 0.2 & 7.6 & 0.4 & 0.1 & 0.0 & 0.0 & 0.0 & 0.1 & 17.1 \\
\hline Thailand & 1.2 & -0.3 & 0.1 & 0.3 & 0.1 & 0.2 & 0.1 & 0.2 & 7.3 & 0.1 & 0.1 & 0.1 & 0.0 & 0.1 & 13.7 \\
\hline Rest of Asia & 0.5 & 0.2 & 0.1 & 0.2 & 0.0 & 0.1 & 0.1 & 0.1 & 0.1 & 0.0 & 0.0 & 0.0 & 0.0 & 0.0 & 5.8 \\
\hline Chile & 0.9 & 0.5 & 0.0 & 0.3 & 0.0 & 0.0 & 0.1 & 0.1 & 0.1 & 5.4 & 0.3 & 0.1 & 0.0 & 0.0 & 11.3 \\
\hline Mexico & -1.1 & 0.2 & 0.0 & 0.1 & 0.0 & 0.1 & 0.0 & 0.0 & 0.0 & 0.1 & 5.3 & 0.1 & 0.0 & 0.1 & 6.7 \\
\hline CAC & 3.4 & 1.1 & 0.0 & 0.4 & 0.0 & 0.1 & 0.1 & 0.1 & 0.1 & 0.1 & 0.2 & 5.1 & 0.0 & 0.1 & 14.8 \\
\hline South America & 0.3 & 0.2 & 0.0 & 0.1 & 0.0 & 0.0 & 0.0 & 0.1 & 0.1 & 0.1 & 0.1 & 0.1 & 0.0 & 0.1 & 5.3 \\
\hline Morocco & 1.2 & 1.0 & 0.0 & 0.1 & 0.0 & 0.1 & 0.0 & 0.1 & 0.1 & 0.0 & 0.1 & 0.1 & 3.5 & 0.1 & 10.9 \\
\hline SACU & 0.6 & -0.1 & 0.0 & 0.1 & 0.0 & 0.0 & 0.0 & 0.1 & 0.1 & 0.0 & 0.1 & 0.1 & 0.0 & 7.4 & 8.5 \\
\hline
\end{tabular}




\section{References}

Andriamananjara, Soamiely and Marinos Tsigas. 2003. "Free Trade Agreements with the United States: What Can We Learn from 65 Simulations?" U.S. International Trade Commission, Washington, D.C. (June 5).

Bhagwati, Jagdish and Arvind Panagariya. 1996. "Preferential Trading Areas and Multilateralism Strangers, Friends, or Foes?" in Jagdish Bhagwati and Arvind Panagariya (eds.), The Economics of Preferential Trade Agreements. Washington, D.C.: American Enterprise Institute.

Brown, Drusilla K. and Robert M. Stern. 1989a. "Computational Analysis of the U.S.-Canadian Free Trade Agreement: The Role of Product Differentiation and Market Structure," in Robert C. Feenstra (ed.), Trade Policies for International Competitiveness. Chicago: University of Chicago Press.

Brown, Drusilla K. and Robert M. Stern. 1989b. "Computable General Equilibrium Estimates of the Gains from U.S.-Canadian Trade Liberalization," in David Greenaway, Thomas Hyclak, and Robert J. Thornton (eds.), Economic Aspects of Regional Trading Arrangements. London: Harvester Wheatsheaf.

Brown, Drusilla K., Alan V. Deardorff, and Robert M. Stern. 2000. "Computational Analysis of the Accession of Chile to the NAFTA and Western Hemisphere Integration," The World Economy 23(2): 145-174.

Brown, Drusilla K., Alan V. Deardorff and Robert M. Stern. 2002. "CGE Modeling and Analysis of Multilateral and Regional Negotiating Options," in Robert M. Stern (ed.), Issues and Options for U.S.-Japan Trade Policies. Ann Arbor: University of Michigan Press.

Brown, Drusilla K., Alan V. Deardorff, and Robert M. Stern. 2003. "Multilateral, Regional, and Bilateral Trade-Policy Options for the United States and Japan," The World Economy 26:803-828.

Brown, Drusilla K., Kozo Kiyota, and Robert M. Stern. 2005a. "Computational Analysis of the Free Trade Area of the Americas (FTAA)," North American Journal of Economics and Finance, 16(2): 153-185.

Brown, Drusilla K., Kozo Kiyota, and Robert M. Stern. 2005b. "Computational Analysis of the U.S FTAs with Central America, Australia, And Morocco," The World Economy, 28(10): 1445-1490.

Brown, Drusilla K., Kozo Kiyota, and Robert M. Stern. 2006. "Computational Analysis of the Menu of U.S.-Japan Trade Policies," The World Economy, 29(6): 805-55.

Brown, Drusilla K., Kozo Kiyota, and Robert M. Stern. 2008. "An Analysis of a U.S.-SACU Free Trade Agreement," World Development, 36(3): 461-484.

Deardorff, Alan V., and Robert M. Stern. 1990. Computational Analysis of Global Trading Arrangements. Ann Arbor: University of Michigan Press.

DeRosa, Dean and John Gilbert. 2004. "Technical Appendix: Quantitative Estimates of the Economic Impacts of US Bilateral Free Trade Agreements," in Jeffrey J. Schott, Free Trade Agreements: US Strategies and Priorities. Washington, D.C.: Institute for International Economics.

Dimaranan, Betina V. and Robert A. McDougall. 2002. "Command Line Data Aggregation Program," in Betina V. Dimaranan and Robert A. McDougall. (eds.), The GTAP 5 Data Base. West Lafayette, IN: Center for Global Trade Analysis, Department of Agricultural Economics, Purdue University.

Francois, Joseph and Anna Strutt. 1999. "Post Uruguay Round Tariff Vectors for GTAP Version 4," Erasmus University, manuscript. 
Francois, Joseph, Hans van Meijl, and Frank van Tongeren. 2003. "Trade Liberalization and Developing Countries under the Doha Round," CEPR Discussion Paper Series No. 4032 (August).

Harrison, W. J. and Ken Pearson. 1996. "Computing Solutions for Large General Equilibrium Models using GEMPACK," Computational Economics, 9(2): 83-127.

Hertel, Thomas W. 2000. "Potential Gains from Reducing Trade Barriers in Manufacturing, Services and Agriculture," Federal Reserve Bank of St. Louis Review, 82: 77-99.

Hertel, Thomas W. and Martin, W. 2000. "Liberalizing Agriculture and Manufactures in a Millennium Round: Implications for Developing Countries," The World Economy, 23(4): 455-469.

Hertel, Thomas W and Martin, W. 2001. "Second-best Linkages and the Gains from Global Reform of Manufactures Trade," Review of International Economics, 9(2): 215-32.

Hertel, Thomas W., Terrie Walmsley, and Ken Itakura. 2001. "Dynamic Effects of the 'New Age' Free Trade Agreement between Japan and Singapore," Journal of Economic Integration, 16(4): 446-84.

Hoekman, Bernard. 2000. "The Next Round of Services Negotiations: Identifying Priorities and Options," Federal Reserve Bank of St. Louis Review, 82: 31-47.

Hoekman, B. and Martin, W. (eds.) 2001. Developing Countries and the WTO: a Pro-Active Agenda (Oxford: Blackwell).

International Labor Organization (ILO). 2003. LABORSTA (http://laborsta.ilo.org/cgi-bin/brokerv8.exe).

Ianchovichina, Elena and William Martin. 2004. "Economic Impacts of China’s Accession to the WTO," in D. Bhattasali, Shantong Li, and William Martin. (eds.), China and the WTO: Accession, Policy Reform, and Poverty Reduction Strategies. Washington, D.C.: Oxford University Press and the World Bank.

Kiyota, Kozo and Robert M. Stern. 2007. The Economic Effects of a Korea-U.S. Free Trade Agreement, Special Study, Korea Economic Institute, Washington, D.C., April.

Krishna, K. 2006. 'Understanding Rules of Origin', in O. adot, A. Estevadordal, A. Suwa-Eisenmann, and T. Verdier (eds.), The Origin of Goods: Rules of Origin in Regional Trade Agreements, New York: Oxford University Press.

McKibbin, W.J., J-W Lee, and I Cheong. 2004. "A Dynamic Analysis of the Korea-Japan Free Trade Area: Simulations with the G-Cubed Asia-Pacific Model," International Economic Journal, 18(1): 332.

Stolper, Wolfgang and Paul A. Samuelson. 1941. "Protection and Real Wages," Review of Economic Studies, 9(1): 58-73.

Taiwan Government. 2003. (www.stat.gov.tai/bs2/2002YearBook.pdf).

United Nations Industrial Development Organization (UNIDO). 2003. UNIDO Industrial Statistics Database 2003 at the 3-digit Level of ISIC (Revision 2) on CD-ROM. Geneva: UNIDO.

World Bank. 2003. World Development Indicators on CD-ROM. Washington, D.C.: World Bank. 